\title{
Landslides behavior spatial modeling by using evidential belief function model, Promethean II model, and index of entropy in Tabriz, Iran
}

\author{
Ziba Beheshti $^{1} \cdot$ Alireza Gharagozlou $^{2} \cdot$ Masoud Monavari $^{1} \cdot$ Mirmasoud Kheirkhah Zarkesh $^{3}$ \\ Received: 10 January 2021 / Accepted: 31 July 2021 / Published online: 17 August 2021 \\ (C) Saudi Society for Geosciences 2021
}

\begin{abstract}
Due to the increasing construction of clay and marl hills in most areas of Tabriz (Iran), its characteristics in terms of resistance, and its tendency to liquefy during earthquakes, this city is at risk of landslides. This paper studies the landslide vulnerability of Tabriz using visual and statistical evidence. The evaluation of landslide susceptibility was performed using the evidential belief function model (EBF) and the index of entropy. The environmental impact assessment of landslides was carried out using the Promethean II model in three environmental, economic, and social phases. Finally, a landslide strategy plan for decision-makers was developed. The results of the analysis using the EBF model showed that $89.81 \%$ of the total area of Tabriz is located in a direct landslide vulnerability zone. The output of the receiver operating characteristics (ROC) curve showed $83.3 \%$ accuracy of the EBF model. The impact assessment showed that for the environment, the geological criterion had an output weight of 0.396; for the economy, the road criterion had a weight of 0.477 ; and for the society, the commercial criterion had a weight of a 0.452 ; all were the most affected by landslides. The results of monitoring studies of the largest landslides in Tabriz in 1957, 1984, and 2020 showed approximately $41.65 \mathrm{~m}$ of land sliding over a period of 63 years. To our knowledge, this study is the first in the world to predict the environmental impact assessment and provide a strategy plan for Tabriz.
\end{abstract}

Keywords Landslide susceptibility assessment $\cdot$ Environmental effects $\cdot$ Mitigation option $\cdot$ Strategy process $\cdot$ Monitoring process

Responsible Editor: Biswajeet Pradhan

Alireza Gharagozlou

a_gharagozlo@sbu.ac.ir

Ziba Beheshti

zibabeheshti64@gmail.com

Masoud Monavari

Monavarism@yahoo.com

Mirmasoud Kheirkhah Zarkesh

Kheirkhah@alumni.itc.nl

1 Department of Environmental Science, Faculty of Natural Resources and Environment, Islamic Azad University, Science and Research Branch, Tehran, Iran

2 Faculty of Civil Water and Environmental Engineering, Shahid Beheshti University, Tehran, Iran

3 Soil Conservation and Watershed Management Research Institute, AREEO, Tehran, Iran

\section{Introduction}

Landslides in the form of mass movements pose threats to human safety and security, the environment, and the economy (Pandey et al. 2021; Nsengiyumva et al. 2018). According to the Construction Ministry of Jihad in Iran, 15,000 landslides have occurred in Iran since 2006. The earthquakes of 1721 and 1780 were the worst natural disasters in the North Tabriz Fault: the first killed 100,000 people in the northeastern of Tabriz, and the second killed a total of 200,000 people in Tabriz and Turkey. Considering the occurrence of numerous historical earthquakes and the resulting complete destruction of Tabriz 12 times, the North Tabriz Fault has been propounded as one of the well-known seismic faults of Tabriz (Ahadnezhad Reveshty et al. 2014). Landslide disaster risk reduction is an important common goal in all countries/regions where people living in mountains and slopes are prone to landslides (Akawwi et al. 2018; Vilímek et al. 2020). Landslide susceptibility can be generally defined as the probability of landslide occurring in 

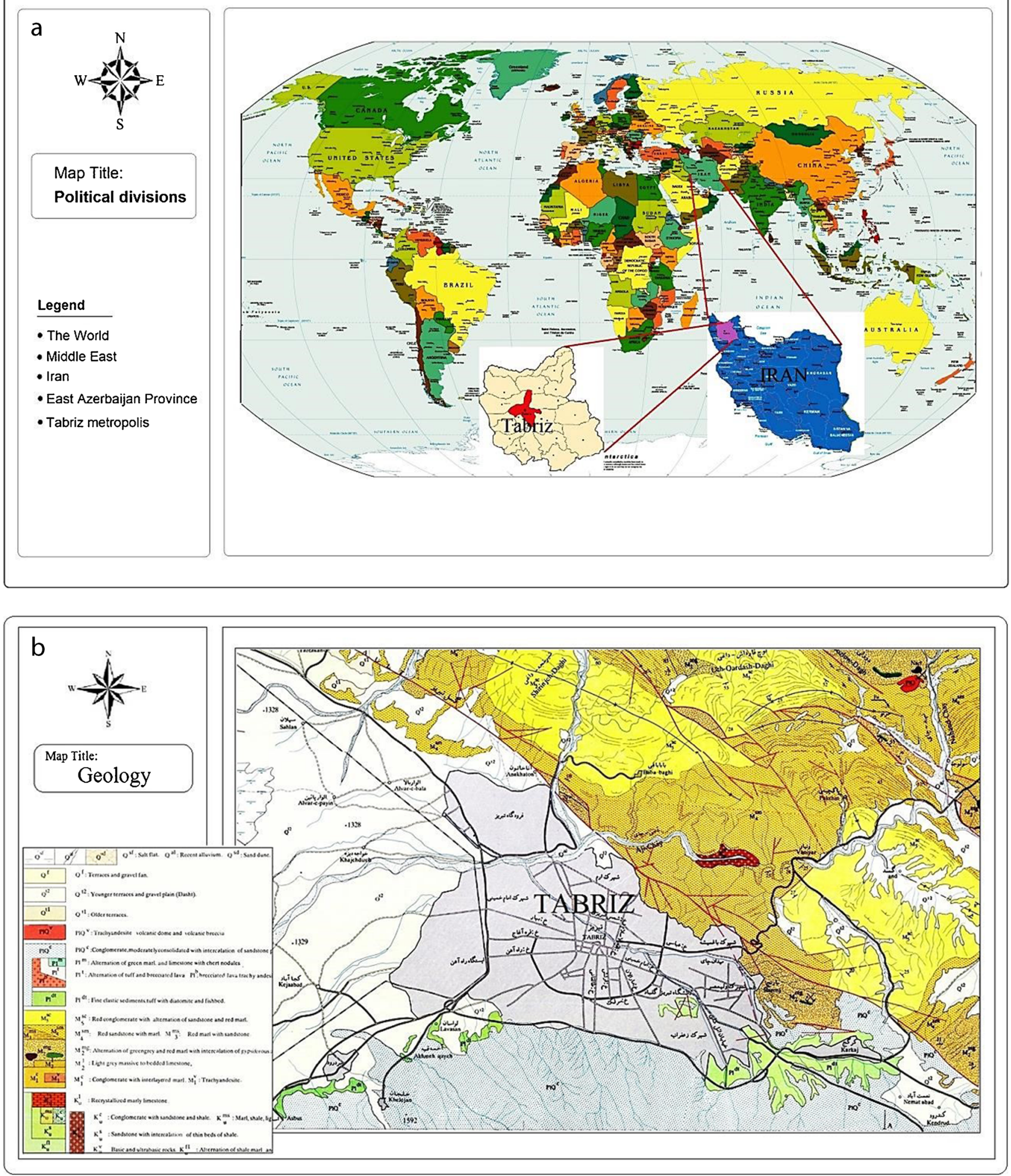

Fig. 1 Location map of the study area (a) Geological map of Tabriz (b)

areas under the coupling action of a series of geological environmental factors and human activities (Chen et al. 2019a). The assessment of landslides in the world suggests that most developing countries are at greater risk of landslides (Pradhan and Siddique 2020; Sah et al. 2018). 
Table 1 Morphometric of Tabriz linked to 1956 landslide

\begin{tabular}{llllll}
\hline Volume $\left(\mathrm{m}^{3}\right)$ & Sphere $(\mathrm{m})$ & Area $\left(\mathrm{m}^{2}\right)$ & Width $(\mathrm{m})$ & Length $(\mathrm{m})$ & Landslide of 1957 \\
\hline 13539761.74 & 2539.36 & 85386.53 & 327.53 & 983.39 & Main slip boundary \\
2164892.64 & 1043.74 & 25892.85 & 259.64 & 372.58 & Small slip border, left \\
317974.86 & 534.58 & 6798.63 & 168.63 & 213.63 & Small slip border, right \\
17376928.85 & 4728.09 & 438967.39 & 971.53 & 1987.52 & Great slip border \\
\hline
\end{tabular}

Assessing the risk of landslide occurrence can help predict the probability and return period of landslide in an area (He et al. 2019; Mateos et al. 2020). The consequence of landslides becomes more hazardous if they occur along or near townships (Puente-Sotomayor et al. 2021). This phenomenon has attracted the attention of the global scientific community, leading to the publication of a large number of studies examining landslide risk assessment (Dikshit et al. 2020; Sassa 2019; Bičer and Ercanoglu 2020). All of the above studies concluded that for a landslide risk assessment, it is essential to have access to recorded information and results of previous research studies. However, in Tabriz, despite previous landslides incidents and damage to infrastructure and housing "especially in highly developing areas of the city without respecting the laws and regulations of urban planning and geology," there is no reliable scientific research to determine vulnerability to future events. The lack of information regarding the potential damage caused by a severe landslide hazard in
Tabriz, being a large metropolis with a particular economic and international situation in Iran, requires an in-depth scientific study and elimination of the research gap in the assessment of landslide in this city. In the event of a landslide, areas that comply with the principles and regulation of urban planning and geology will not significantly be impacted (Skilodimou et al. 2019; Shaaban et al. 2021). The assessment of the environmental effects of landslides showed an inverse relationship between the severity of landslides and the extent of urban infrastructure (Fahad et al. 2019) and the level of noncompliance to urban development regulations (Usman et al. 2020). This study focuses on the vulnerability of areas with low living standards (Ayala 2019) in Tabriz. Reducing landslide losses requires an appropriate method to identify the prone area, causal factors, and likelihood of future occurrence ( $\mathrm{Li}$ et al. 2020; Confuorto et al. 2019). Landslide susceptibility mapping (LSM) has proven to be an effective module for detecting and predicting

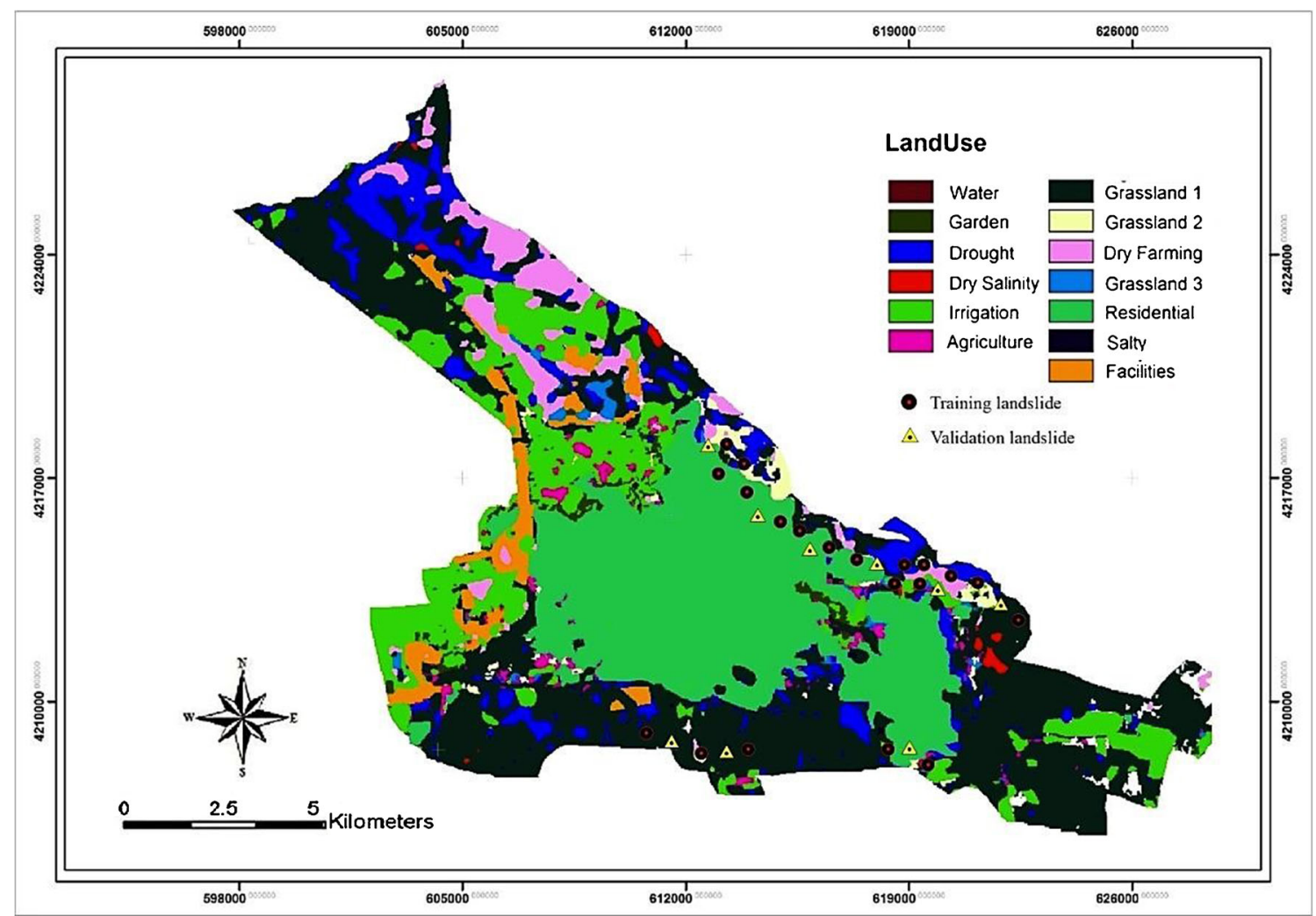

Fig. 2 Map of landslides identified in Tabriz 
Table 2 Data describing landslides in the study

\begin{tabular}{|c|c|c|c|c|c|}
\hline & Category & Factors & Data type & Scale & \\
\hline Digital elevation model & Topographic factors & $\begin{array}{l}\text { Slope } \\
\text { Aspect } \\
\text { Elevation }\end{array}$ & Grid & $1: 25000$ & $\begin{array}{l}\text { National geographic information } \\
\text { institute (NGII) } \\
\text { Iran national geographic center, } \\
\text { www.ncc.gov.ir }\end{array}$ \\
\hline Soil map & $\begin{array}{l}\text { Topography } \\
\text { Lithology } \\
\text { Landslide } \\
\text { Erosion }\end{array}$ & & Polygon & $1: 5000$ & $\begin{array}{l}\text { Forests, range, and watershed } \\
\text { management organization (FRWC) }\end{array}$ \\
\hline Fault map & & Distance from fault density & Line & $\begin{array}{l}1: 5000 \\
1: 4000\end{array}$ & $\begin{array}{l}\text { Geological survey and mineral } \\
\text { exploration of Iran (gsi.ir) } \\
\text { Google Map }\end{array}$ \\
\hline Power line map & Infrastructure factors & $\begin{array}{l}\text { Distance from oil line } \\
\text { Distance from gas network }\end{array}$ & Line & $1: 5000$ & $\begin{array}{l}\text { East Azerbaijan agricultural } \\
\text { organization, www.eaj.ir }\end{array}$ \\
\hline Hydrographic map & Rivers & Distance from main and minor rivers & Line & $1: 5000$ & $\begin{array}{l}\text { Water and sewerage of East Azerbaijan } \\
\text { Province, en.abfaazarbaijan.ir }\end{array}$ \\
\hline
\end{tabular}

landslide-susceptible areas (Nhu et al. 2020; Park et al. 2018; Feizizadeh et al. 2014).

Various machine-learning methods have been used for geotechnical applications such as landslide susceptibility mapping, groundwater spring potential mapping, and other environmental applications (Schäfer and Wenzel 2019; Zhao and Chen 2020Selecting an appropriate mapping unit is an important step for landslide susceptibility evaluation. Statistical models, such as evidential belief function (EBF), have been widely used for generating landslide susceptibility maps (Feby et al. 2020). The EBF model is best suited for integration in different environmental and socioeconomic scenarios enhancing the models for urban allocation tasks (Arasteh et al. 2019; Pradhan et al. 2014; Bui et al. 2016). Successful use of the model by other researchers suggests that the EBF model is suitable for data analysis with GIS (Deng et al. 2017). Recent advances in remote sensing (RS) and geographic information system (GIS) technology have dramatically improved the efficiency of the LSM module and the reliability of its results (Tavakkoli Piralilou et al. 2019). In this study, due to the investigation of various urban components such as economic, social, and environmental components, the EBF model was used as a dual model for sociospatial measurement between landslides and conditional factors. The receiver operating characteristic (ROC) is a graphical plot that calculates the area under the ROC curve (AUC) (Thi Ngo et al. 2021); the focus is on the positive rate (Murillo et al. 2019). The second model is the entropy of index (IOE), which is based on the bivariate analysis principle (Shirani et al. 2018). The Preference Ranking Organization Method for Enrichment of Evaluations (PROMETHEE) method has been used by many researchers, for the location of wind farms

Table 3 Types of landslides identified in Tabriz

\begin{tabular}{|c|c|c|c|c|c|c|c|}
\hline $\begin{array}{l}\text { Distance from the } \\
\text { main river }\end{array}$ & $\begin{array}{l}\text { Distance from } \\
\text { fault }\end{array}$ & $\begin{array}{l}\text { Distance from } \\
\text { residential areas }\end{array}$ & $\begin{array}{l}\text { Distance from the } \\
\text { road }\end{array}$ & Lithology & $\begin{array}{l}\text { Landslide } \\
\text { position }\end{array}$ & Type of landslide & \\
\hline- & - & $5 \mathrm{~m}$ & $1 \mathrm{~m}$ & $\begin{array}{l}\text { Shill sandstone and } \\
\text { red marn }\end{array}$ & $\begin{array}{l}\text { Pasdaran } \\
\text { highway }\end{array}$ & Swing slip & 1 \\
\hline $50 \mathrm{~m}$ & $500 \mathrm{~m}$ & $20 \mathrm{~m}$ & - & Green and gray marn & Valiasr & Swing slip & 2 \\
\hline $100 \mathrm{~m}$ & $50 \mathrm{~m}$ & $20 \mathrm{~m}$ & - & $\begin{array}{l}\text { Granular deposits and } \\
\text { tuff }\end{array}$ & Valiasr & Swing Slip & 3 \\
\hline- & $500 \mathrm{~m}$ & $20 \mathrm{~m}$ & $3 \mathrm{~m}$ & $\begin{array}{l}\text { Shill sandstone and } \\
\text { red marn }\end{array}$ & Yaghchian & Swing Slip & 4 \\
\hline- & - & $30 \mathrm{~m}$ & $1 \mathrm{~m}$ & $\begin{array}{l}\text { Shill sandstone and } \\
\text { red marn }\end{array}$ & $\begin{array}{l}\text { Pasdaran } \\
\text { highway }\end{array}$ & $\begin{array}{l}\text { Crushing and } \\
\text { overturning }\end{array}$ & 5 \\
\hline- & - & $10 \mathrm{~m}$ & $1 \mathrm{~m}$ & $\begin{array}{l}\text { Shill sandstone and } \\
\text { red marn }\end{array}$ & $\begin{array}{l}\text { Pasdaran } \\
\text { highway }\end{array}$ & $\begin{array}{l}\text { Crushing and } \\
\text { overturning }\end{array}$ & 6 \\
\hline- & - & $5 \mathrm{~m}$ & $5 \mathrm{~m}$ & $\begin{array}{l}\text { Shill sandstone and } \\
\text { red marn }\end{array}$ & $\begin{array}{l}\text { Baghmishe } \\
\text { township }\end{array}$ & $\begin{array}{l}\text { Crushing and } \\
\text { overturning }\end{array}$ & 7 \\
\hline- & - & $5 \mathrm{~m}$ & $1 \mathrm{~m}$ & $\begin{array}{l}\text { Shill sandstone and } \\
\text { red marn }\end{array}$ & $\begin{array}{l}\text { Baghmishe } \\
\text { township }\end{array}$ & Stone slip & 8 \\
\hline
\end{tabular}




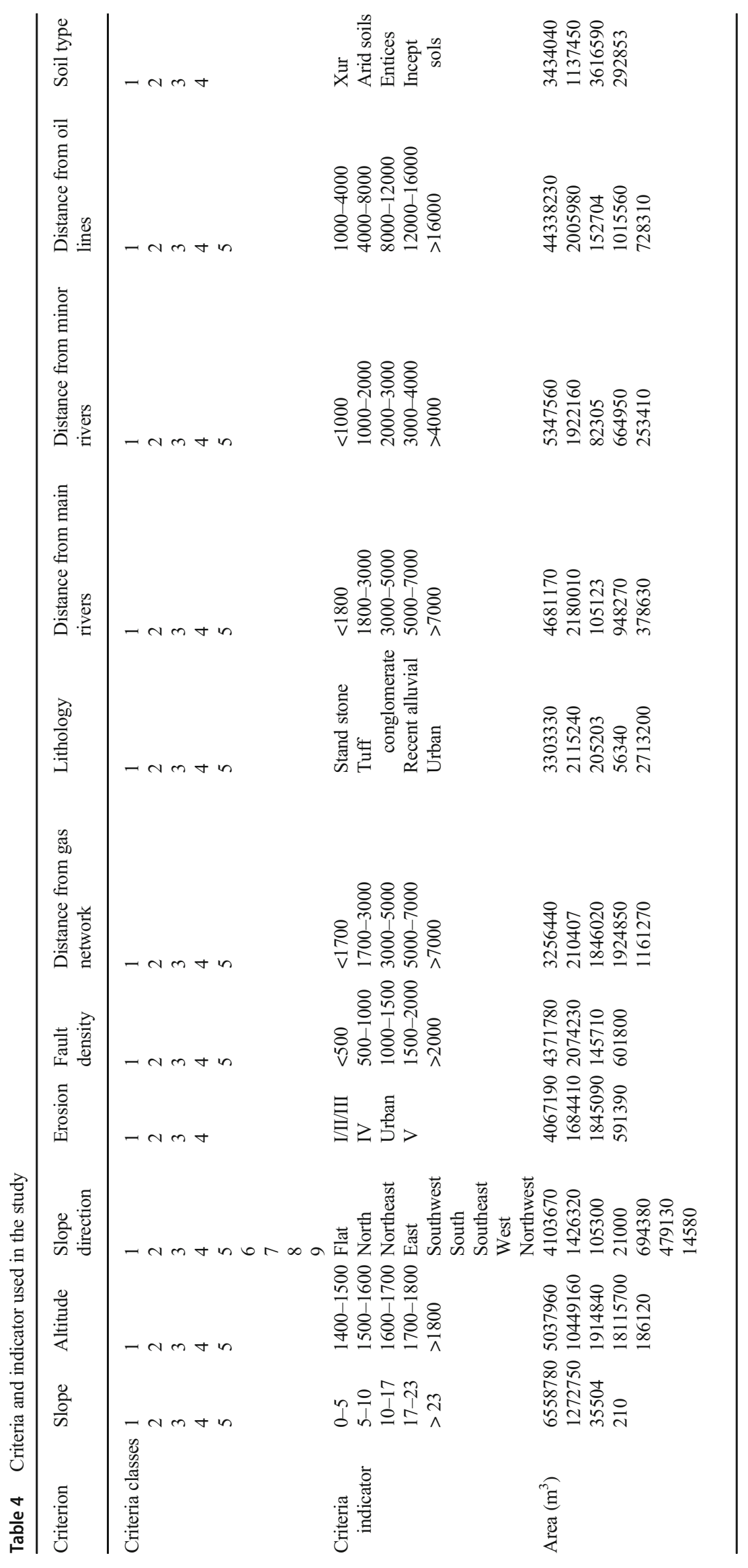


Table 5 Classification of criteria calculated in EBF model

\begin{tabular}{|c|c|c|c|c|c|c|c|c|}
\hline PLS & UNC & DIS & BEL & $\begin{array}{l}\text { Cumulative } \\
\text { percentage }\end{array}$ & $\begin{array}{l}\text { Percentage of } \\
\text { total layer }\end{array}$ & Area $\left(\mathrm{m}^{2}\right)$ & Class & \\
\hline 0.95 & 0.7 & 0.05 & 0.25 & 80.10 & 80.10 & 6558780 & $0-5.99$ & \multirow[t]{4}{*}{ Slope } \\
\hline 0.88 & 0.78 & 0.12 & 0.10 & 95.64 & 15.54 & 1272750 & $5.99-11.98$ & \\
\hline 0.94 & 0.74 & 0.06 & 0.20 & 99.99 & 4.35 & 356340 & $11.98-17.97$ & \\
\hline 0.93 & 0.78 & 0.07 & 0.15 & 100 & 0.002 & 210 & $17.97-23.96$ & \\
\hline 0.80 & 0.75 & 0.2 & 0.05 & 61.52 & 61.52 & 5037960 & $1400-1502$ & \multirow[t]{4}{*}{ High see level } \\
\hline 0.90 & 0.8 & 0.1 & 0.10 & 74.34 & 12.81 & 1049160 & $1502-1605$ & \\
\hline 0.94 & 0.74 & 0.06 & 0.20 & 97.72 & 23.38 & 1914840 & $1605-1707$ & \\
\hline 0.95 & 0.7 & 0.05 & 0.25 & 100 & 2.27 & 186120 & $1707-1810$ & \\
\hline 0.88 & 0.78 & 0.12 & 0.10 & 49.67 & 49.67 & 4067190 & $\mathrm{I} / \mathrm{II} / \mathrm{III}$ & \multirow[t]{4}{*}{ Erosion } \\
\hline 0.90 & 0.75 & 0.1 & 0.15 & 70.25 & 20.57 & 1684410 & IV & \\
\hline 0.95 & 0.75 & 0.05 & 0.20 & 77.46 & 7.22 & 591390 & $\mathrm{~V}$ & \\
\hline 0.93 & 0.75 & 0.07 & 0.18 & 100 & 22.53 & 1845090 & Urban & \\
\hline 0.90 & 0.82 & 0.1 & 0.08 & 50.11 & 50.11 & 4103670 & Flat & \multirow[t]{9}{*}{ Slope direction } \\
\hline 0.92 & 0.77 & 0.08 & 0.015 & 67.53 & 17.14 & 1426320 & North & \\
\hline 0.85 & 0.8 & 0.15 & 0.05 & 68.82 & 1.28 & 105300 & Northeast & \\
\hline 0.80 & 0.75 & 0.2 & 0.05 & 69.07 & 0.25 & 21000 & East & \\
\hline 0.91 & 0.81 & 0.09 & 0.10 & 69.25 & 0.17 & 14580 & Southeast & \\
\hline 0.94 & 0.76 & 0.06 & 0.18 & 75.10 & 5.85 & 479130 & South & \\
\hline 0.95 & 0.75 & 0.05 & 0.20 & 83.58 & 8.48 & 694380 & Southwest & \\
\hline 0.94 & 0.78 & 0.06 & 0.16 & 93.11 & 9.52 & 779580 & West & \\
\hline 0.90 & 0.82 & 0.1 & 0.08 & 100 & 6.88 & 564120 & Northwest & \\
\hline 0.90 & 0.8 & 0.1 & 0.10 & 39.77 & 39.77 & 3256440 & $0-2166$ & \multirow[t]{4}{*}{ Gas network } \\
\hline 0.93 & 0.78 & 0.07 & 0.15 & 62.31 & 22.54 & 1846020 & $2166-4334$ & \\
\hline 0.91 & 0.78 & 0.09 & 0.13 & 85.81 & 23.50 & 1924850 & $4334-6500$ & \\
\hline 0.94 & 0.78 & 0.06 & 0.18 & 100 & 14.18 & 1161270 & $6500-8667$ & \\
\hline 0.94 & 0.76 & 0.06 & 0.18 & 54.20 & 54.20 & 4438230 & $0-5061$ & \multirow[t]{4}{*}{ Oil pipelines } \\
\hline 0.95 & 0.75 & 0.05 & 0.30 & 78.70 & 24.49 & 2005980 & $5061-10122$ & \\
\hline 0.93 & 0.78 & 0.07 & 0.15 & 91.10 & 12.40 & 1015560 & $10122-15184$ & \\
\hline 0.88 & 0.8 & 0.12 & 0.08 & 100 & 8.89 & 728310 & $15184-20245$ & \\
\hline 0.80 & 0.76 & 0.2 & 0.04 & 40.34 & 40.34 & 3303300 & Sand stone & \multirow[t]{4}{*}{ Lithology } \\
\hline 0.93 & 0.65 & 0.07 & 0.26 & 66.17 & 25.83 & 2115240 & $\begin{array}{l}\text { Tuff } \\
\text { conglomerate }\end{array}$ & \\
\hline 0.80 & 0.75 & 0.2 & 0.05 & 66.86 & 0.68 & 56340 & Recent alluvial & \\
\hline 0.95 & 0.65 & 0.05 & 0.30 & 100 & 33.13 & 2713200 & Urban & \\
\hline 0.95 & 0.65 & 0.05 & 0.30 & 53.39 & 53.39 & 4371780 & $0-3334$ & \multirow[t]{4}{*}{ Fault density } \\
\hline 0.92 & 0.72 & 0.08 & 0.20 & 78.72 & 25.33 & 2074230 & $3334-6669$ & \\
\hline 0.92 & 0.74 & 0.08 & 0.18 & 92.65 & 13.92 & 1140270 & 669-10004 & \\
\hline 0.90 & 0.74 & 0.1 & 0.15 & 100 & 7.34 & 601800 & 10004-13338 & \\
\hline 0.93 & 0.7 & 0.07 & 0.23 & 57.17 & 57.17 & 4681170 & 0.2251 & \multirow[t]{4}{*}{ Main rivers } \\
\hline 0.90 & 0.77 & 0.1 & 0.18 & 83.79 & 26.62 & 2180010 & $2251-4502$ & \\
\hline 0.88 & 0.78 & 0.12 & 0.10 & 95.37 & 11.58 & 948270 & $4502-6754$ & \\
\hline 0.85 & 0.77 & 0.15 & 0.08 & 100 & 4.62 & 378630 & $6754-9005$ & \\
\hline 0.95 & 0.72 & 0.05 & 0.23 & 65.30 & 65.30 & 5347560 & $0-1099$ & \multirow[t]{4}{*}{ Minor rivers } \\
\hline 0.91 & 0.77 & 0.09 & 0.14 & 88.78 & 23.47 & 1922160 & 1099-2198 & \\
\hline 0.93 & 0.75 & 0.07 & 0.18 & 96.90 & 8.12 & 664950 & 2198-3297 & \\
\hline 0.86 & 0.76 & 0.14 & 0.10 & 100 & 3.9 & 253410 & $3297-4397$ & \\
\hline
\end{tabular}

(Amarasinghe and Perera 2020 the evaluation of tourist attraction (Tian et al. 2020), sustainable composing technology (Makan and Fadili 2020), the socioeconomic vulnerability of urban (Contreras et al. 2020). The concept of social vulnerability (SV) to environmental hazards that involves demographic and socioeconomic factors that affect community 
Table 6 Degree of vulnerability of Tabriz regions with EBF model

\begin{tabular}{lllll}
\hline $\begin{array}{l}\text { Percentage } \\
(\%)\end{array}$ & Area of each floor $\left(\mathrm{m}^{2}\right)$ & Pixel area $\left(\mathrm{m}^{2}\right)$ & Number of pixels $(\mathrm{n})$ & \\
\hline 13.14 & 30880075 & 25 & 131465 & $\begin{array}{c}\text { Very high } \\
\text { vulnerability }\end{array}$ \\
23.73 & 56491875 & & 237315 & High vulnerability \\
46.03 & 128550825 & 25 & 4603024 & Moderate vulnerability \\
11.34 & 23178850 & 25 & 113475 & Low vulnerability \\
5.76 & 14134125 & 25 & 57633 & Very low vulnerability \\
\hline
\end{tabular}

resilience is considered a hot topic in the current disaster research (Shen et al. 2018). The most common spatial variables used to assess the economic and social vulnerability of a city between 2010 and 2020 include the housing of poor families, the number of important facilities (fire stations and medical centers) (Rezaei et al. 2019), the distance from the fault, and faults causing landslides (Hizbaron et al. 2012). The above studies show that in the context of landslide hazards, especially in urban areas, most landslide sensitivity zoning and comparison of model superiority were carried out (Abbaszadeh Shahri et al. 2019), and the role of proper location and fair distribution of urban infrastructure in reducing the destructive effects of landslides was not considered. The occurrence of an earthquake can shift the movement of the Tabriz fault to a more activated state. The consequences of such rapid developments, regardless of regional potential, will be significant environmental destructions and heavy financial losses for residents and urban settlements.

Two examples of these consequences include first, the landslides in the Valiasr Town residential complexes in Tabriz during 1993-1994 (the slip site remains so far) and second, the landslides and destructions of the Northern Highway of Tabriz and its reconstruction costs.

This study aims to identify the slippery and vulnerable areas of Tabriz, where the consequences of growing lowcost illegal construction must be taken into consideration.
This study also examines the impact of landslide scale on the city's underground infrastructure. The innovative aspect of this paper is that it evaluates the impact of landslide category in an urban environment applying the environmental impact assessment (EIA) tool and including parameters such as landslide sensitivity mapping, landslide impacts assessment, and mitigation, and monitoring.

\section{Study area and data}

This research was conducted in the geographical area of Tabriz (Iran). Tabriz is a city situated at north latitude $30^{\circ} 12^{\prime}$ and east longitude $46^{\circ} 16^{\prime}$. Tabriz lies on the eastern point of the Tabriz plain and the intersection of two rough ranges in the north and south of the city; its area is $70388 \mathrm{~km}^{2}$. Geologically, Tabriz is located in an area with various combinations of formations that show intense tectonic activity (Fig. 1). The most significant landslide in Tabriz occurred in 1956 due to a strong and deadly earthquake with a magnitude of 7.2; in fact, it was the largest and also the most dangerous landslide in Tabriz (Table 1). This paper presents an application development study conducted through diverse methods, including literature review, field observations, modeling, aerial photography, and satellite photo interpretation. First, the potential and susceptible landslide locations were identified using satellite images by completing extensive field
Table 7 Weighting, standardization, and entropy model uncertainty

\begin{tabular}{llllll}
\hline Adjusted weight & Criteria weight & Uncertainty value & Entropy value & Criterion & \\
\hline 0.117 & 0.117 & 0.21 & $99 \%$ & Slope & 1 \\
0.296 & 0.296 & 0.53 & $97 \%$ & Altitude & 2 \\
0.216 & 0.216 & 0.039 & $98 \%$ & Slope direction & 3 \\
0.063 & 0.063 & 0.011 & $99 \%$ & Lithology & 4 \\
0.029 & 0.029 & 0.005 & $99 \%$ & Erosion & 5 \\
0.2 & 0.2 & 0.004 & $99 \%$ & Fault density & 6 \\
0.007 & 0.007 & 0.001 & $95 \%$ & Distance from oil lines & 7 \\
0.026 & 0.026 & 0.005 & $96 \%$ & Distance from gas network & 8 \\
0.096 & 0.096 & 0.017 & $96 \%$ & Distance from main rivers & 9 \\
0.12 & 0.12 & 0.021 & $97 \%$ & Distance from minor rivers & 10 \\
0.1 & 0.1 & 0.002 & $96 \%$ & Soil type & 11 \\
\hline
\end{tabular}




\section{Option}

Environmental impacts assessment Geological

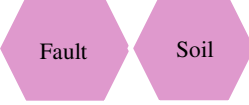

Erosion

Slope

Economic impacts assessment

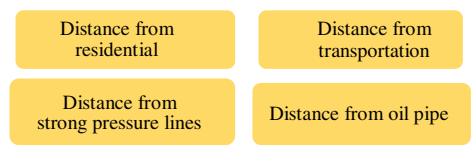

Social impacts assessment
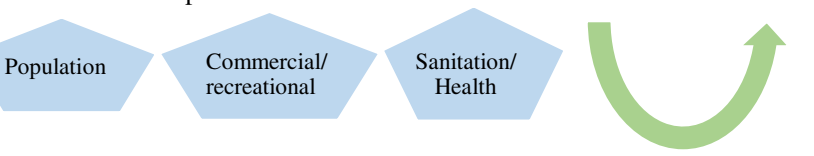

Fig. 3 Social impact assessment
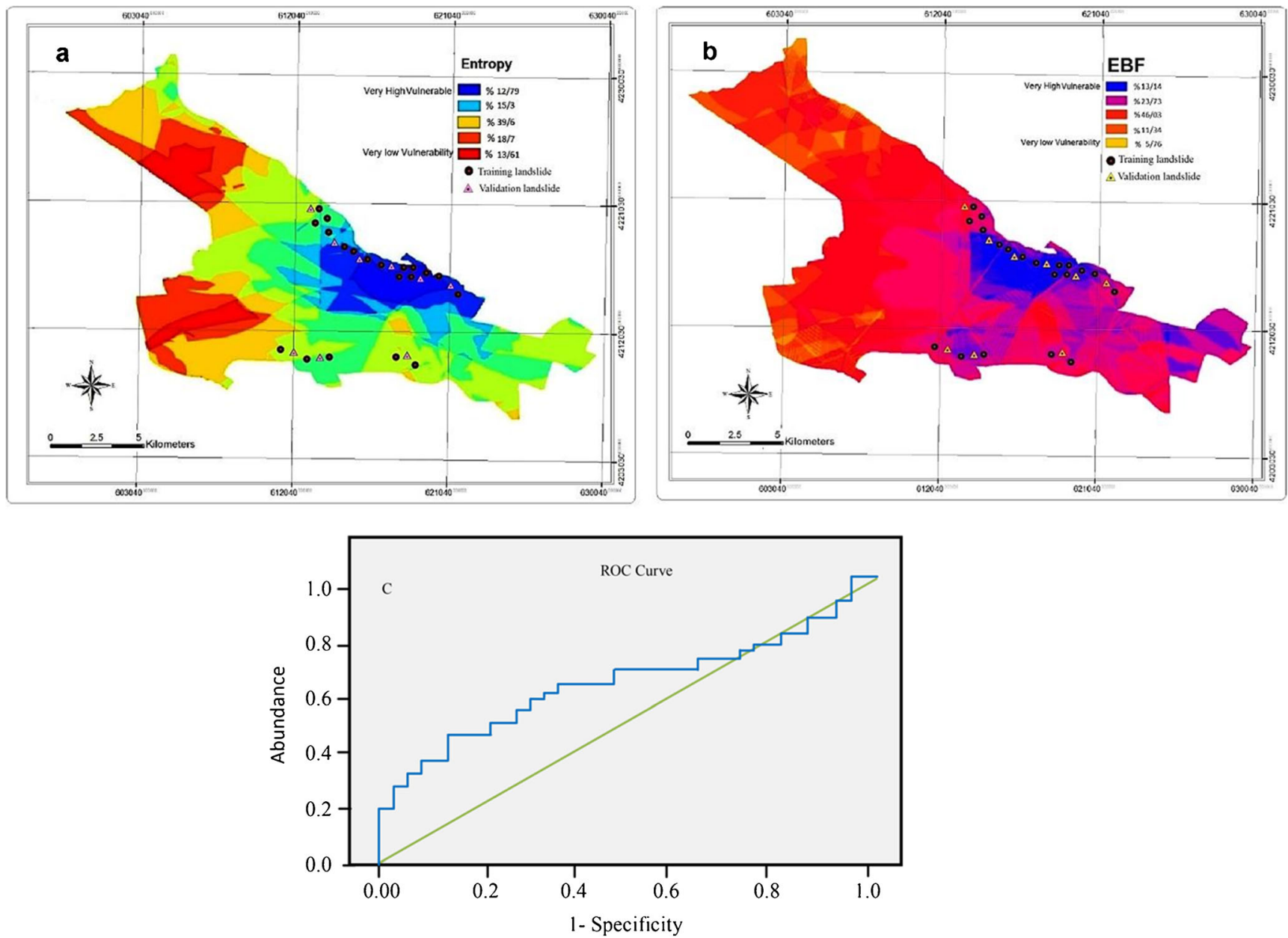

Fig. 4 Results of the entropy model map and the EBF model. The results of the entropy model map revealed the direct and indirect vulnerability of $67.69 \%$ of the Tabriz area zone in terms of landslides (a). The results of the EBF model map revealed the direct and indirect vulnerability of $82.90 \%$ of the Tabriz area zone in terms of landslides. The difference

\section{Criterion}

Importance of impact

Intensity of impact

Direct and indirect
Human activity

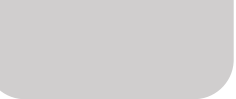


Table 8 The relationship between the effective landslide factors and the sliding points using event weight probabilistic model

\begin{tabular}{|c|c|c|c|c|c|c|c|c|c|c|c|c|c|}
\hline $\mathrm{C} / \mathrm{SC}$ & $\mathrm{SC}$ & $\mathrm{S} 2(\mathrm{~W}-)$ & $\mathrm{S} 2(\mathrm{~W}+)$ & $\mathrm{C}$ & W- & $\mathrm{W}+$ & FR & $\%$ LSD & N-LSD & $\% \mathrm{CLS}$ & N-PIX & Classic & \\
\hline-231.1 & 0.012 & 0.000 & 0.000 & -2.749 & 1.690 & -1.060 & 0.38 & 30.18 & 10143 & 80.10 & 218626 & $0-5$ & \multirow[t]{4}{*}{ Slope } \\
\hline 178.2 & 0.011 & 0.000 & 0.000 & 1.949 & -0.514 & 1.435 & 3.01 & 46.84 & 15741 & 15.54 & 42425 & $5-11$ & \\
\hline 217.7 & 0.013 & 0.000 & 0.000 & 2.824 & -0.243 & 2.581 & 5.25 & 22.96 & 7717 & 4.35 & 11878 & $11-17$ & \\
\hline 6.44 & 0.447 & 0.000 & 0.200 & 2.880 & 0.000 & 2.879 & 5.80 & 0.01 & 5 & 0.00 & 7 & $17-23$ & \\
\hline-17.90 & 0.500 & 0.000 & 0.250 & -8.94 & 0.650 & -8.229 & 0.00 & 0.01 & 4 & 41.94 & 114468 & ARIDOSOL & \multirow[t]{2}{*}{ Soil } \\
\hline 63.07 & 0.013 & 0.000 & 0.000 & 0.804 & -0.143 & 0.661 & 1.74 & $\begin{array}{l}24 . \\
12\end{array}$ & 81.07 & 13.89 & 37915 & URBAN & \\
\hline 122.57 & 0.013 & 0.000 & 0.000 & 1.562 & -0.915 & 0.647 & 1.72 & 75.86 & 25495 & 44.17 & 120553 & INCEPTISOL & \multirow{10}{*}{ Slope direction } \\
\hline-6.54 & 0.039 & 0.000 & 0.002 & -0.275 & 0.821 & 0.567 & 0.04 & 1.97 & 661 & 50.12 & 136789 & Flat & \\
\hline 14.60 & 0.096 & 0.000 & 0.009 & 1.401 & 0.218 & 1.618 & 0.02 & 0.32 & 109 & 17.42 & 47544 & North & \\
\hline-2.71 & 0.005 & 0.000 & 0.000 & -0.015 & 0.015 & 0 & 0.00 & 0.00 & 0 & 1.29 & 3510 & Northeast & \\
\hline-0.54 & 0.005 & 0.000 & 0.000 & -0.003 & 0.003 & 0 & 0.00 & 0.00 & 0 & 0.26 & 700 & East & \\
\hline 118.54 & 0.046 & 0.000 & 0.002 & 5.495 & -0.014 & 5.481 & 7.89 & 1.40 & 472 & 0.18 & 486 & Southeast & \\
\hline 377.71 & 0.011 & 0.000 & 0.000 & 4.199 & -0.507 & 3.63 & 6.90 & 40.36 & 13565 & 5.85 & 15971 & South & \\
\hline 192.75 & 0.012 & 0.000 & 0.000 & 2.235 & -0.35 & 1.884 & 3.90 & 33.08 & 11118 & 8.48 & 18804 & Southwest & \\
\hline 98.3 & 0.013 & 0.000 & 0.000 & 1.274 & -0.18 & 1.094 & 2.40 & 22.84 & 7677 & 9.52 & 25986 & West & \\
\hline-13.15 & 0.500 & 0.000 & 0.250 & -6.574 & 0.082 & -6.492 & 0.00 & 0.01 & 4 & 6.89 & 564120 & Northwest & \\
\hline-163.43 & 0.015 & 0.000 & 0.000 & -2.521 & 0.984 & -1.537 & 0.24 & 14.65 & 4924 & 61.53 & 167932 & $1400-1500$ & \multirow[t]{4}{*}{ Elevation } \\
\hline 97.72 & 0.012 & 0.000 & 0.000 & 1.186 & -0.217 & 0.967 & 2.19 & 28.10 & 9444 & 12.81 & 34972 & $1500-1600$ & \\
\hline 114.76 & 0.011 & 0.000 & 0.000 & 1.255 & -0.408 & 0.847 & 2.00 & 46.85 & 15745 & 23.39 & 63828 & $1600-1700$ & \\
\hline 129.51 & 0.018 & 0.000 & 0.000 & 2.315 & -0.098 & 2.217 & 4.57 & 10.39 & 3493 & 2.27 & 6204 & $1700-1800$ & \\
\hline-153.22 & 0.005 & 0.000 & 0.000 & -0.836 & 0.836 & 0.000 & 0.00 & 0.00 & 0 & 49.67 & 135573 & $3 / 2 / 1$ & \multirow[t]{4}{*}{ Erosion } \\
\hline-70.66 & 0.028 & 0.000 & 0.001 & -1.990 & 0.220 & -1.770 & 0.19 & 3.90 & 1312 & 20.57 & 56147 & 4 & \\
\hline 113.61 & 0.013 & 0.000 & 0.000 & 1.531 & -0.177 & 1.354 & 2.86 & 20.66 & 6944 & 7.22 & 19713 & 5 & \\
\hline 224.77 & 0.013 & 0.000 & 0.000 & 2.848 & -1.240 & 1.608 & 3.35 & 75.43 & 25350 & 22.53 & 61503 & Urban & \\
\hline-110.44 & 0.005 & 0.000 & 0.000 & -0.603 & 0.603 & 0.000 & 0.00 & 0.12 & 40 & 39.77 & 108548 & $0-2166$ & \multirow{4}{*}{$\begin{array}{l}\text { Distance from gas } \\
\text { network }\end{array}$} \\
\hline-65.37 & 0.020 & 0.000 & 0.000 & -1.307 & 0.197 & -1.109 & 0.36 & 8.11 & 2724 & 22.55 & 61534 & $2166-4333$ & \\
\hline 92.64 & 0.011 & 0.000 & 0.000 & 1.023 & -0.316 & 0.707 & 1.80 & 42.30 & 14216 & 23.50 & 64145 & $4333-6500$ & \\
\hline 2.7 .61 & 0.011 & 0.000 & 0.000 & 2.265 & -0.586 & 1.679 & 3.49 & 49.47 & 16626 & 14.18 & 38709 & $6500-8667$ & \\
\hline-109.60 & 0.005 & 0.000 & 0.000 & -0.602 & 0.602 & 0.000 & 0.03 & 1.16 & 390 & 40.34 & 110110 & Sandstone & \multirow[t]{4}{*}{ Lithology } \\
\hline-64.48 & 0.061 & 0.000 & 0.004 & -3.933 & 0.339 & -3.594 & 0.03 & 0.81 & 271 & 25.83 & 70508 & Tuff & \\
\hline-1.44 & 0.005 & 0.000 & 0.000 & -0.008 & 0.008 & 0.000 & 0.00 & 0.00 & 0 & 0.69 & 1878 & Recent & \\
\hline 128.79 & 0.039 & 0.002 & 0.000 & 5.059 & $3.653-$ & 1.406 & 2.96 & 93.03 & 32925 & 33.14 & 90440 & Urban & \\
\hline 92.34 & 0.016 & 0.000 & 0.000 & 1.450 & -1.450 & 0.000 & 1.65 & 87.92 & 29548 & 53.39 & 145726 & $0-334$ & \multirow[t]{4}{*}{ Distance from fault } \\
\hline-59.76 & 0.017 & 0.000 & 0.000 & -1.001 & 0.189 & -0.812 & 0.48 & 12.08 & 4058 & 25.33 & 69141 & $3434-6669$ & \\
\hline-31.70 & 0.005 & 0.000 & 0.000 & -0.173 & 0.173 & 0.000 & 0.00 & 0.00 & 0 & 13.93 & 38009 & 6669-10004 & \\
\hline-16.05 & 0.005 & 0.000 & 0.000 & -0.088 & 0.088 & 0.000 & 0.00 & 0.00 & 0 & 7.35 & 20060 & 10004-13338 & \\
\hline 85.14 & 0.036 & 0.001 & 0.000 & 3.023 & -3.023 & 0.000 & 1.71 & 97.64 & 32813 & 57.17 & 156039 & $0-2251$ & \multirow{4}{*}{$\begin{array}{r}\text { Distance from } \\
\text { Main River }\end{array}$} \\
\hline-80.05 & 0.036 & 0.000 & 0.001 & -2.877 & 0.333 & -2.554 & 0.09 & 2.36 & 793 & 26.62 & 72667 & $2551-4502$ & \\
\hline-25.97 & 0.005 & 0.000 & 0.000 & -0.142 & 0.142 & 0.000 & 0.00 & 0.00 & 0 & 11.58 & 31609 & $4502-6754$ & \\
\hline-9.93 & 0.005 & 0.000 & 0.000 & -0.054 & 0.054 & 0.000 & 0.00 & 0.00 & 0 & 4.62 & 12621 & $6754-9005$ & \\
\hline-26.78 & 0.07 & 0.000 & 0.000 & -0.198 & 0.198 & 0.000 & 0.84 & 45.63 & 15336 & 54.20 & 147941 & $0-5061$ & \multirow{4}{*}{$\begin{array}{l}\text { Distance from } \\
\text { oil lines }\end{array}$} \\
\hline 140.84 & 0.011 & 0.000 & 0.000 & 1.542 & -0.558 & 0.985 & 2.22 & 54.37 & 18270 & 24.50 & 66866 & $5061-10122$ & \\
\hline-27.96 & 0.005 & 0.000 & 0.000 & -0.153 & 0.153 & 0.000 & 0.00 & 0.00 & 0 & 12.40 & 33852 & $10122-15184$ & \\
\hline-19.61 & 0.005 & 0.000 & 0.000 & -0.107 & 0.107 & 0.000 & 0.00 & 0.00 & 0 & 8.89 & 24277 & 15184-20245 & \\
\hline 44.59 & 0.012 & 0.000 & 0.000 & 0.523 & -0.523 & 0.000 & 1.20 & 78.35 & 26329 & 65.31 & 178252 & 0-1099 & \multirow{4}{*}{$\begin{array}{l}\text { Distance from } \\
\text { Minor river }\end{array}$} \\
\hline-15.46 & 0.014 & 0.000 & 0.000 & -0.210 & 0.046 & -0.163 & 0.87 & 20.31 & 6827 & 23.48 & 22165 & 1099-2198 & \\
\hline-14.86 & 0.005 & 0.000 & 0.000 & -0.082 & 0.082 & 0.000 & 0.16 & 1.34 & 450 & 8.12 & 8447 & 2198-3296 & \\
\hline-6.59 & 0.005 & 0.000 & 0.000 & -0.036 & 0.036 & 0.000 & 0.00 & 0.00 & 0 & 3.09 & & $3297-4397$ & \\
\hline
\end{tabular}




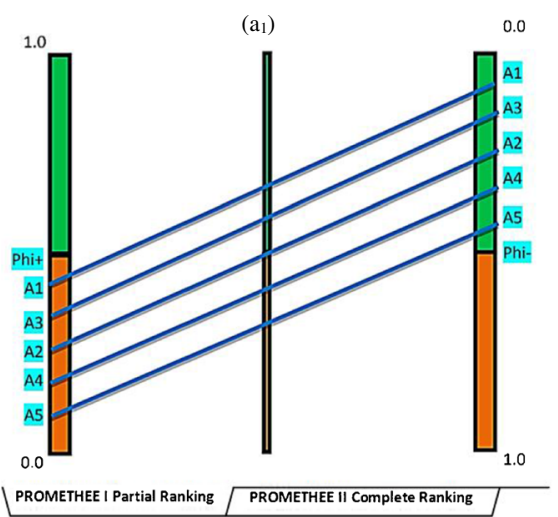

$\left(b_{1}\right)$

Scenario1: Environmental effects of landslide: $\mathrm{A}_{1}$ (geology) $>\mathrm{A}_{3}$ (fault) $>\mathrm{A}_{2}$ (soil) $>\mathrm{A}_{4}$ (erosion) $>\mathrm{A}_{5}$ (slope)

(a1) PROMETHEE I partial ranking of environmental criteria $\left(b_{1}\right)$ Complete ranking of alternatives based on the PROMETHEE II method, taking into consideration of all categories of possible decisions.

$\left(\mathrm{a}_{2}\right)$

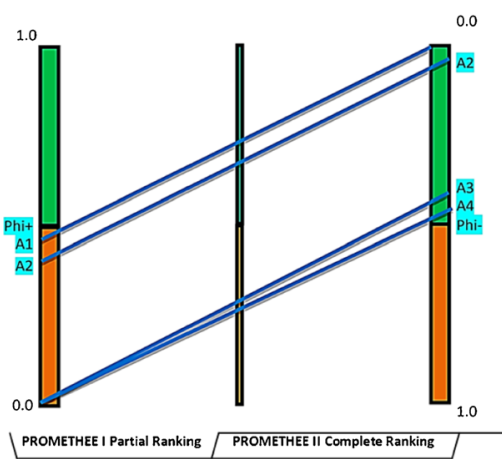

$\left(b_{2}\right)$

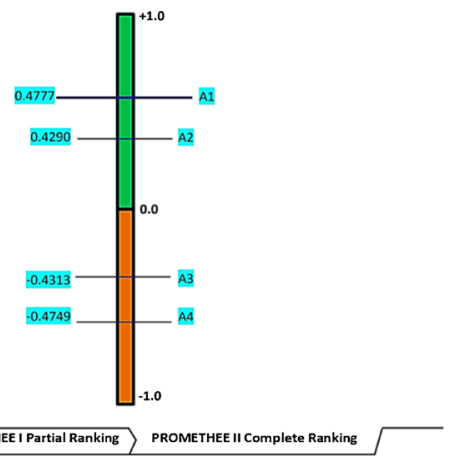

Scenario 2: Economic effects of landslide: $A_{1}$ (Transportation) $>A_{2}$ (Residential) $>A_{3}$ (Pressure lines) $>A_{4}$ (oil pipes)

$\left(a_{2}\right)$ PROMETHEE I partial ranking of economic criteria $\left(b_{2}\right)$ Complete ranking of alternatives based on the PROMETHEE II method, taking into consideration of all categories of possible decisions.

$\left(\mathrm{a}_{3}\right)$

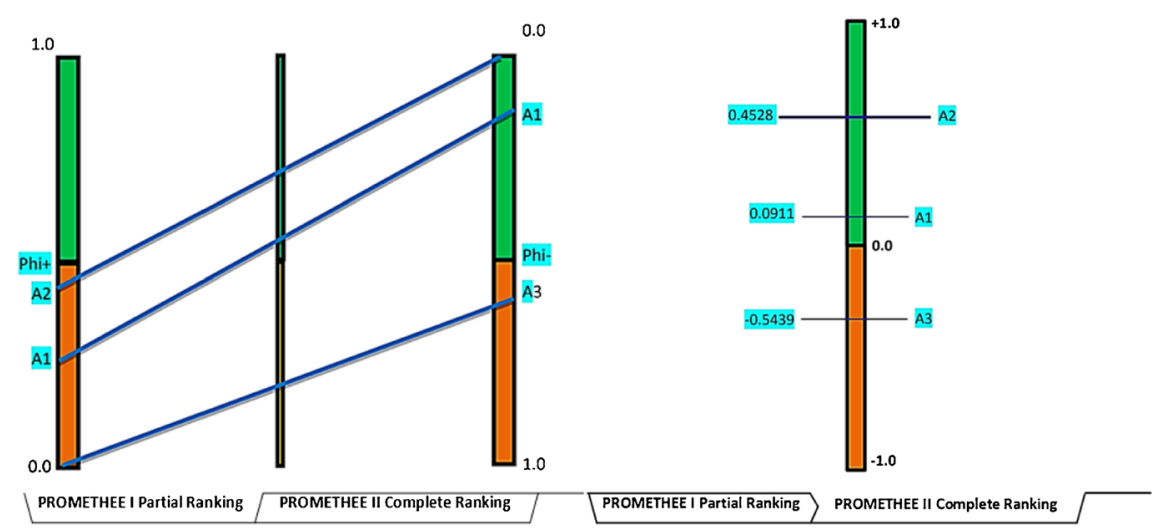

Scenario 3: Social effects of landslide: $A_{2}$ (recreational) $>A_{1}$ (population) $>A_{3}$ (health)

(a) PROMETHEE I partial ranking of social criteria ( $\left.b_{3}\right)$ Complete ranking of alternatives based on the PROMETHEE II method, taking into consideration of all categories of possible decisions.
Fig. 5 Scenario1: Environmental effects of landslide: $A_{1}$ (geology) $>A_{3}$ (fault) $>\mathrm{A}_{2}$ (soil) $>\mathrm{A}_{4}$ (erosion) $>\mathrm{A}_{5}$ (slope) $\left(\mathrm{a}_{1}\right)$ PROMETHEE I partial ranking of environmental criteria $\left(b_{1}\right)$. Complete ranking of alternatives based on the PROMETHEE II method, taking into consideration of all categories of possible decisions. Scenario 2: Economic effects of landslide: $\mathrm{A}_{1}$ (Transportation) $>\mathrm{A}_{2}$ (Residential) $>\mathrm{A}_{3}$ (Pressure lines) $>\mathrm{A}_{4}$ (oil pipes) $\left(a_{2}\right)$ PROMETHEE I partial ranking of economic criteria $\left(b_{2}\right)$
Complete ranking of alternatives based on the PROMETHEE II method, taking into consideration of all categories of possible decisions. Scenario 3: Social effects of landslide: $A_{2}$ (recreational) $>A_{1}$ (population) $>A_{3}$ (health) $\left(a_{3}\right)$ PROMETHEE I partial ranking of social criteria $\left(b_{3}\right)$ Complete ranking of alternatives based on the PROMETHEE II method, taking into consideration of all categories of possible decisions. 

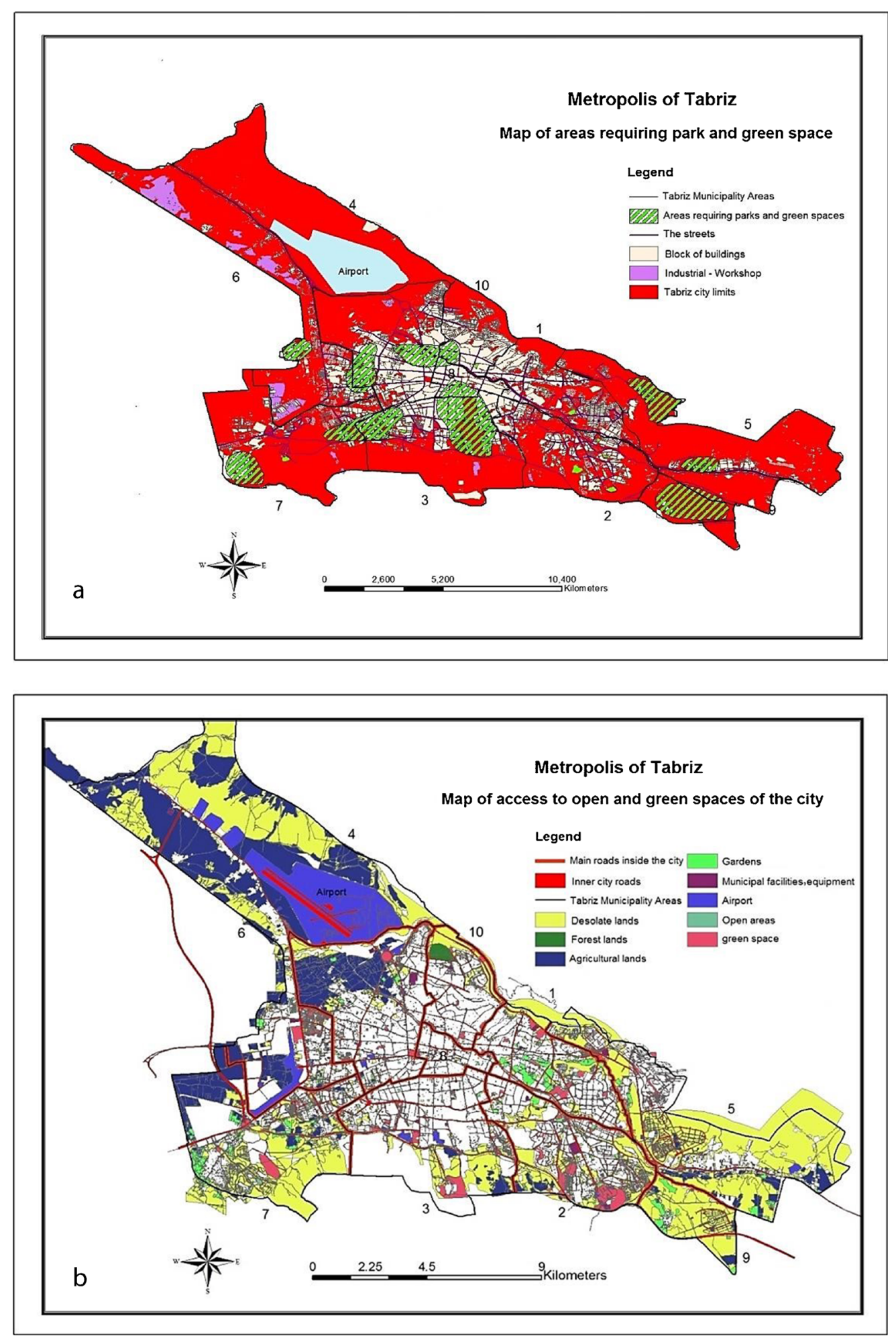

Fig. 6 Areas requiring park and green spaces (a) (areas 3, 4, and 6; dense commercial areas of the city and busy areas) are the areas that encounter a lack of green spaces; meanwhile, Tabriz suffers from a total shortage of 430 ha in terms of green spaces. Accessibility to open and green spaces of

observations and data recorded by GPS to match the existing landslides accurately. ArcGIS 10 software was used to analyze the data and prepare the maps. A total of 29 landslides the city in Tabriz (b). The lack of green space per capita in Tabriz leads to increased severity of vulnerability to landslides and similar accidents. The more people have access to the city's open and green spaces, the less causality will result in the hours after the landslide

were identified (Fig. 2; Tables 2 and 3). The landslide data set was randomly divided into two parts so that $70 \%$ of cases were used for assessment, and $30 \%$ were kept for validating 
Table 9 Area and per capita of Green spaces in Tabriz

\begin{tabular}{|c|c|c|c|c|c|}
\hline \multirow{11}{*}{$\begin{array}{c}430 \\
\text { Hectares } \\
\text { shortages }\end{array}$} & $\left(\mathbf{m}^{2}\right)$ Shortage & Per capita standard & $\left(\mathrm{m}^{2}\right)$ Per capita & $\left(\mathrm{m}^{2}\right)$ Area & region \\
\hline & & 4 & 4.1 & 1546 & 1 \\
\hline & & 4 & 6.7 & 2095 & 2 \\
\hline & 150040 & 4 & 3.4 & 2798 & 3 \\
\hline & 150011 & 4 & 3.1 & 2550 & 4 \\
\hline & & 4 & 8.3 & 3229 & 5 \\
\hline & 300102 & 4 & 0.5 & 7196 & 6 \\
\hline & - & 4 & 11.7 & 2882 & 7 \\
\hline & - & 4 & 12.2 & 386 & 8 \\
\hline & 400151 & 4 & 0.1 & 762 & 9 \\
\hline & 4302154 & 82 & 44 & 1050 & 10 \\
\hline
\end{tabular}

the landslide susceptibility map. In the next step, considering the conditions of the study area, eleven factors determining the occurrence of landslides were analyzed in the GIS environment including the slope degree, slope direction, height above mean sea level, distance from the fault, distance from main rivers, distance from minor rivers, distance from oil pipelines, distance from natural gas networks, erosions, soil type, and lithology. It is noteworthy that the study area was local in scale and had homogeneous conditions in terms of climatic variables; therefore, the rainfall criterion was removed (Table 4).

\section{Methods and materials}

\section{Evidential belief function}

The base of the EBF model used in this study is mainly the Dempster-Shafer theory of evidence algorithms (Dempster 2008; Shafer 1976). The Dempster-Safer theory is a generalization of the Bayesian subjective probability theory, which relates to the effect of confidence index on the probability of related problems. The main advantage of the EBF model is its flexibility which is the result of accepting uncertainty and incorporating many sources of belief (Bui et al. 2012). For this reason, it has already been applied in the construction of landslide susceptibility maps. The EBF model consists of the following four main mathematical functions: Bel (degree of belief), Dis (degree of disbelief), Unc (degree of uncertainty), and Pls (degree of plausibility) (Tables 5 and 6). The values of these functions range from 0 to 1 . Multilayer integration of Bel, Dis, Unc, and Pls is expressed as follows:

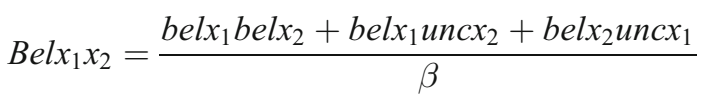

$\operatorname{Disx}_{1} x_{2}=\frac{\operatorname{disx}_{1} d i s x_{2}+\operatorname{disx}_{1} u n c x_{2}+\operatorname{dis}_{2} u n c x_{1}}{\beta}$

$U n c x_{1} x_{2}=\frac{u n c x_{1} u n c x_{2}}{\beta}$ where $\beta=1-$ bel $_{1}$ dis $_{2}-$ dis $_{1}$ bel $x_{2}$ is a normal factor to ensure $\mathrm{BEL}+\mathrm{UNC}+\mathrm{DIS}=10$.

\section{Index of Shannon entropy}

The second model used for landslide susceptibility analysis in the current study is the index of entropy model. The model indicates the extent of the instability, disorder, imbalance, and uncertainty of a system (Youssef et al. 2015) (Table 7). The entropy of a landslide refers to the extent to which various factors influence the development of a landslide. Several important factors provide additional entropy in the index system. Thus, the entropy can be used to calculate the objective weights of the index system. The equations used to calculate the information coefficient $\mathrm{Wj}$, which represents the weight value for the parameter as a whole, are as follows:

Pij $=\frac{b}{a}$

$(P i j)=\frac{P i j}{\sum_{j=1}^{S \mathrm{~S}} \mathrm{Pij}}$

\section{PROMETHEE II}

The Preference Ranking Organization Method for Enrichment Evaluation (PROMETHEE) method is a subgroup of the multiple-criteria decision-making (MCDM) method developed in the early 1980s by Brans et al. (Zhou et al. 2018). The PROMETHEE technique is an outranking approach for a finite set of alternative actions to be ranked and selected among often contradictory criteria. Due to its flexibility and ease of use, it can be used in various fields. The use of the PROMETHEE method can reinforce the confidence and reliability of decision-makers (Fig. 3).

\section{Results}

To study the geology of Tabriz, a regional geological map at a scale of 1:5000 of lithology was analyzed microscopically using 30 thin sections of existing rock 

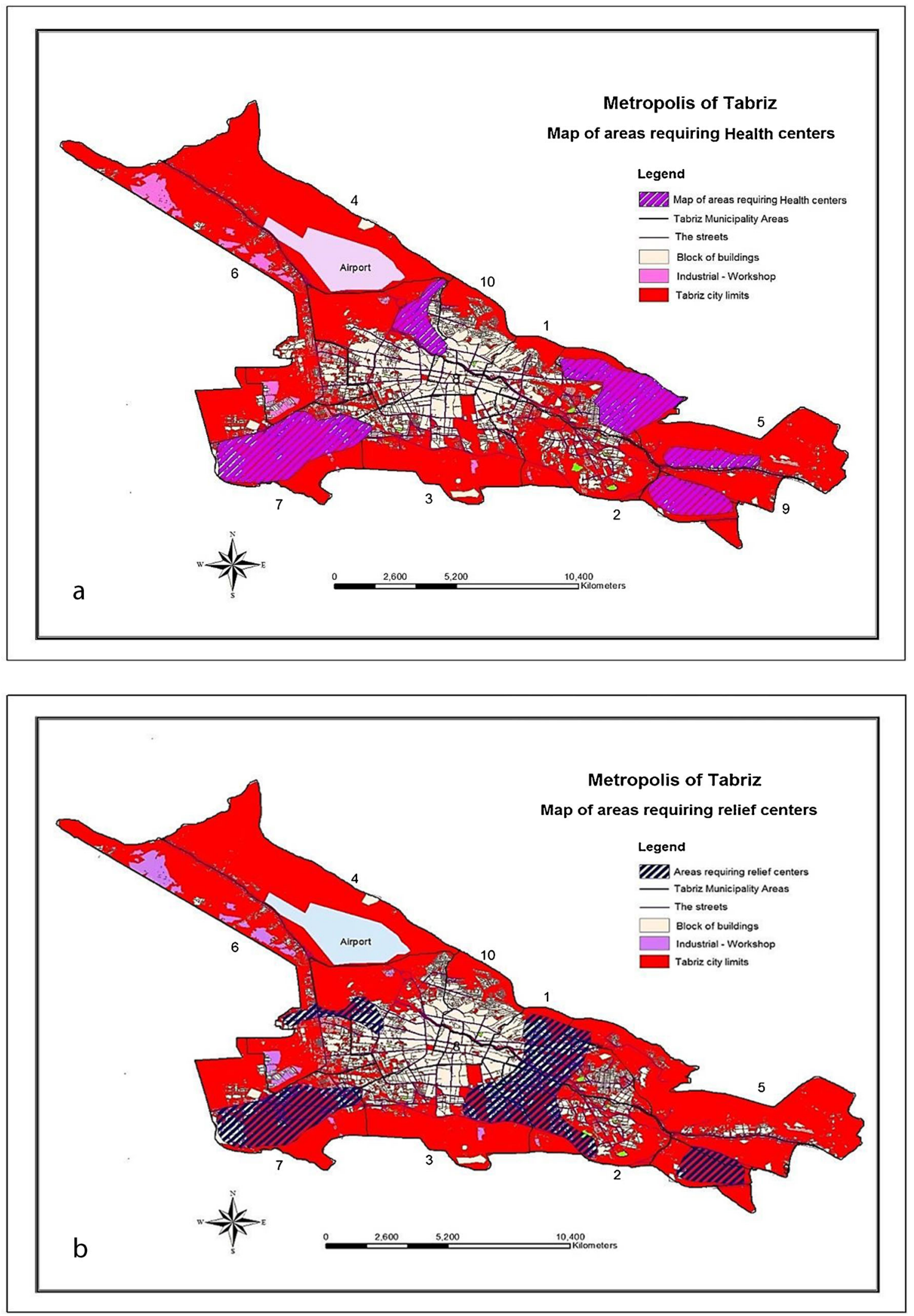

Fig. 7 Distribution of health facilities in Tabriz (a). The zones that require the construction of the necessary relief centers (b). The zones that require the construction of the necessary health centers. Tabriz suffers from a total of 142.6 ha of shortage in terms of healthcare infrastructure 
Table 10 Area and per capita of Health facilities in Tabriz

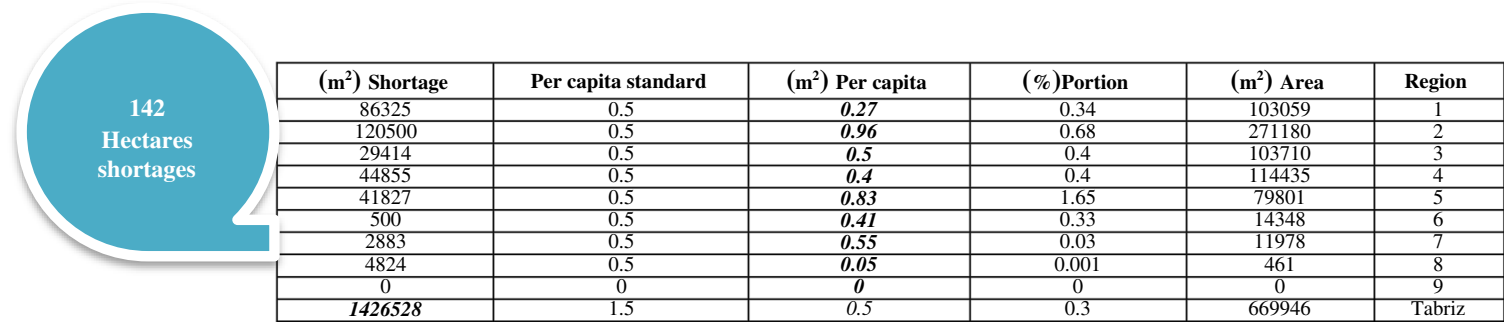

in the region. Regarding the age and structure of the fault and folds of the rocky units of the area, Tabriz geology map at a scale of 1:25000 was used as a reference. In this study, landslide sensitivity in Tabriz city was assessed using EBF and entropy models (Fig. 4; Table 8). The EBF model can be used to summarize the spatial correlation between landslide occurrence and landslide conditioning factor. When the Bel value is zero, the expected landslide risk is also zero. The results of the EBF model showed that the entire Tabriz region was vulnerable at moderate to very high levels; this vulnerability puts $82.9 \%$ of the city at risk of direct and indirect landslides. The entropy model results show that $67.69 \%$ of the city is at risk of landslide. The environmental impact assessment was carried out using the Promethean II model. DecisionLab software was used to run the Promethean II model. To rank the effects of landslides, options and criteria of each of the environmental, economic, and social components were selected, and a pairwise comparison of all options was performed. Of the six types of PROMETHEE model preference indicators, types four and five were considered for the criteria. The normalized weights of each indicator were determined by the decision-makers. For the assessment of the environmental impacts of landslides, criteria included geology, soil, fault, erosions, and slope. The evaluation of the environmental effects of landslides showed that the geological option with a weight of $0.396 \%$ had the most damage due to the landslides risk $\left(A_{1}>A_{3}>A_{2}>A_{4}>A_{5}\right)$. Analyzing the economic outcome of landslides in roads, residential areas, high-pressure lines, and oil lines using

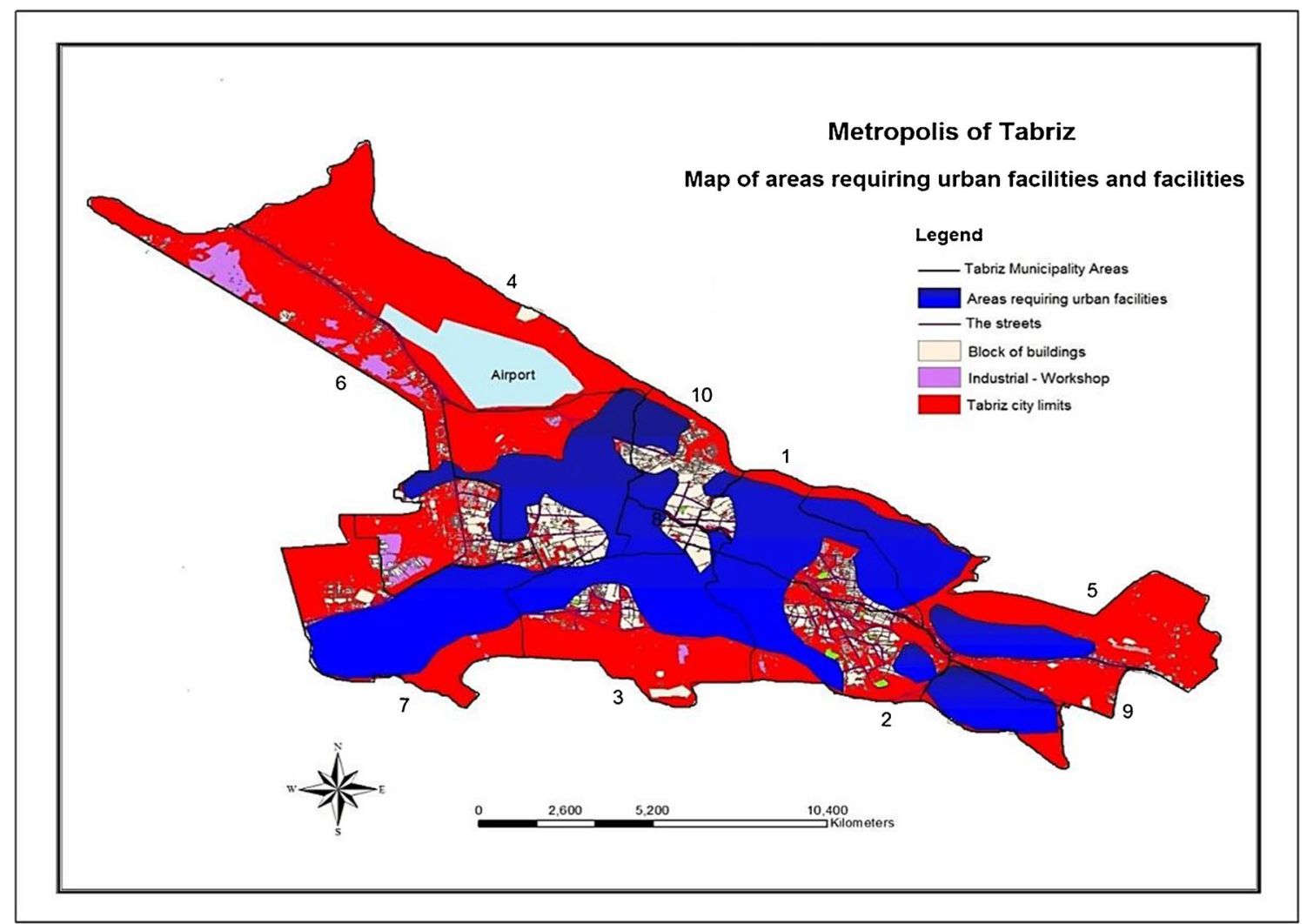

Fig. 8 Accessibility to urban facilities in Tabriz. Nearly 85 ha of the regions of Tabriz suffer from deprivation of accessibility to urban facilities 
Table 11 Area and per capita of facilities and equipment spaces in areas of Tabriz

\begin{tabular}{|c|c|c|c|c|c|c|}
\hline \multirow{11}{*}{$\begin{array}{c}142 \\
\text { Hectares } \\
\text { shortages }\end{array}$} & $\left(\mathrm{m}^{2}\right)$ Shortage & Per capita standard & $\left(\mathrm{m}^{2}\right)$ Per capita & (\%)Portion & $\left(m^{2}\right)$ Area & Region \\
\hline & 86325 & 0.5 & 0.27 & 0.34 & 103059 & 1 \\
\hline & 120500 & 0.5 & 0.96 & 0.68 & 271180 & 2 \\
\hline & 29414 & 0.5 & 0.5 & 0.4 & 103710 & 3 \\
\hline & 44855 & 0.5 & 0.4 & 0.4 & 114435 & 4 \\
\hline & 41827 & 0.5 & 0.83 & $\begin{array}{l}.67 \\
.65\end{array}$ & 79801 & 5 \\
\hline & 500 & 0.5 & 0.41 & 0.33 & 14348 & 6 \\
\hline & 2883 & 0.5 & 0.55 & 0.03 & 11978 & 7 \\
\hline & 4824 & 0.5 & 0.05 & 0.001 & 461 & 8 \\
\hline & 0 & 0 & 0 & 0 & 0 & 9 \\
\hline & 1426528 & 1.5 & 0.5 & 0.3 & 669946 & Tabriz \\
\hline
\end{tabular}

the economic impact criteria showed that the road option with a weight of 0.477 had the most damage due to the landslides $\left(A_{1}>A_{2}>A_{3}>A_{4}\right)$. The evaluation of the social outcome of landslides in population, commercial-recreational areas, and health $\left(\mathrm{A}_{2}>\mathrm{A}_{1}>\right.$ $A_{3}$ ) showed that the commercial/recreational areas had the most damage due to landslides with a weight of 0.452 (Fig. 5). Losses from landslides can be significantly reduced through cooperation between geologists, engineers, and planners, which may reduce the scale of mitigation measures to be taken; therefore, a statistical and detailed study of the quantity and quality of infrastructure in vulnerable physical structures is necessary for dealing with the severity of the effects after a landslide in Tabriz.

\section{Mitigation}

Mitigation is the final stage of the risk management process (Ferlisi et al. 2019). One of the mitigation methods is to compensate for the shortcomings. The main infrastructure and parameters of Tabriz which played a significant role in offsetting the effects of a landslide were studied as follows.

\section{Green space}

Significant parts of the urban spaces in the northwest, southeast, and western parts of Tabriz have been allocated to green spaces and urban open spaces. However, the urban and outdoor spaces in the central part of the city are limited (Fig. 6; Table 9). The more accessible open spaces are in a city, the less damage there will be in natural disasters such as landslides.

\section{Health facilities}

Improving the quantity and quality of medical centers leads to rapid relief of the injured. In the current global Covid-19 pandemic, if any natural disasters occur in Tabriz, medical centers should be able to provide services to the injured people. Tabriz is currently facing a shortage of 142.6 ha of health facilities (Fig. 7; Table 10).

\section{Urban facilities}

Infrastructure networks are vital for citizens' and urban life; the absence or vulnerability of these networks affects the lives of citizens. The facilities of Tabriz that have been less studied include water reservoirs, municipal electricity facilities, telecommunication center, gas facilities, emergency facilities, and fire brigade. There are more than 85 ha of shortages of mentioned facilities in Tabriz (Fig. 8; Table 11).

\section{Vital arterial roads}

The traffic network per capita in Tabriz is $29.3 \mathrm{~m}^{2}$, which seems adequate. However, some surveys show a very uneven distribution of the transport network, with $4.9 \%$ of the urban population uses $12.5 \%$ of the city's urban roads. In comparison, $32.0 \%$ of the population living in the suburbs uses $17.08 \%$ of the city streets; also in these areas, the building density is very high, which greatly increases the vulnerability (Fig. 9). If Tabriz's per capita traffic network does not increase, in the event of a landslide, the increase in population will prevent the rescue team from providing timely assistance.

\section{Important vital infrastructure}

In terms of quality and condition, the structures of the city's vital infrastructure are classified into three types: usable, restored, and destroyed. This research showed that among all important institutions and service centers, the educational centers had the highest frequency in Tabriz and then the administrative, medical, military, and transit system terminals, respectively. Of the identified institutions and centers, $78.7 \%$ are in good condition and usable, $20.7 \%$ are restored, and $0.6 \%$ are destroyed (Fig. 10).

\section{Monitoring}

Remediation and early warning strategies are generally focused on continuous monitoring of the slope displacements, which can provide crucial information on the dynamics and 
evolution of the landslide (Whiteley et al. 2019). The morphometric monitoring and evaluation of the largest landslides in Tabriz were carried out using RS and GIS at three periods of time, including 1957, 1984, and 2020. The relevant data of aerial photographs of 1957 and 1984 with a scale of 1:5000 (soil and water studies of Iran) and a satellite image of Google
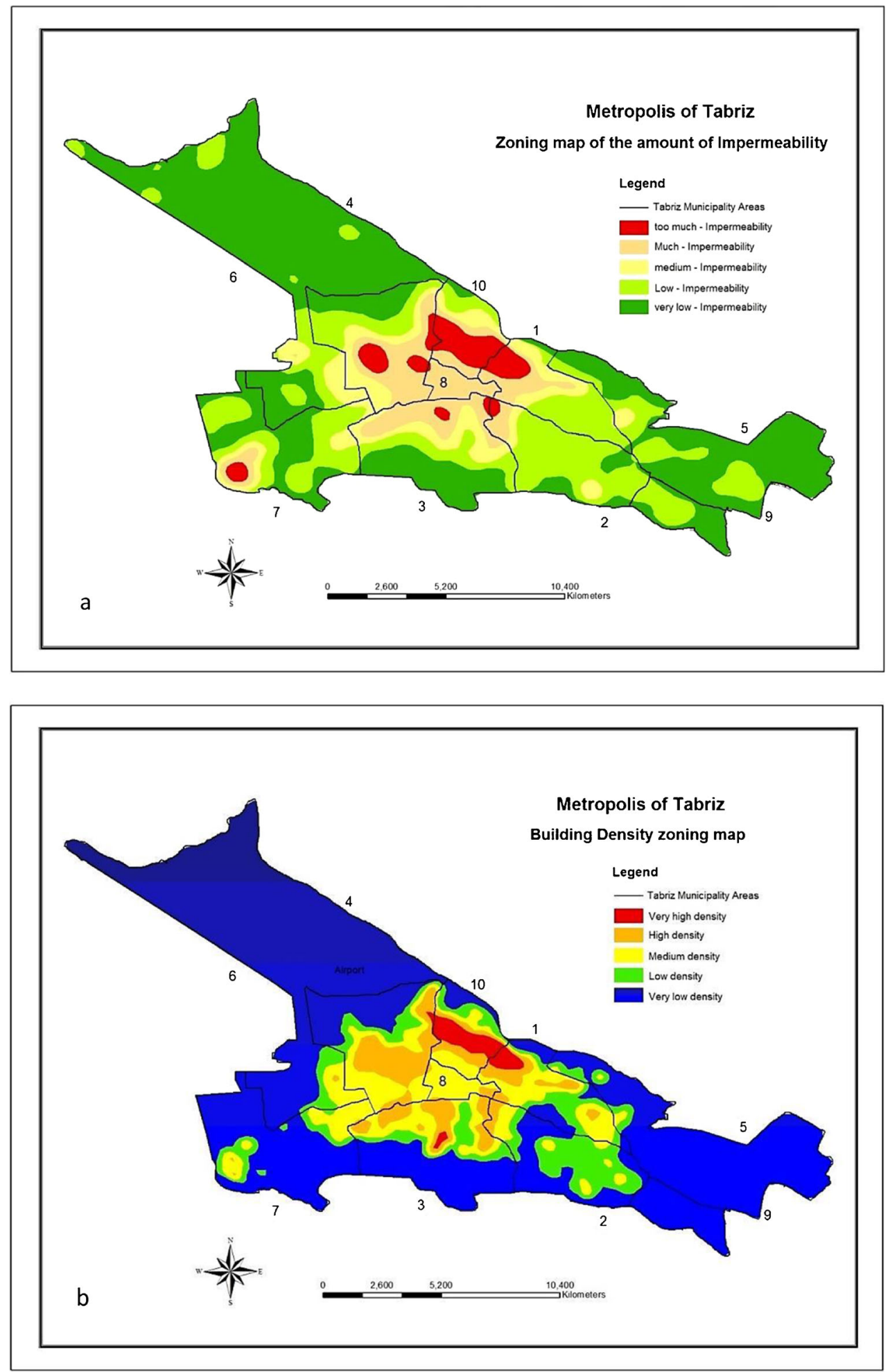

Fig. 9 The degree of impermeability in Tabriz (a); as shown in the map, the highest impermeability was observed in areas where the greatest risk for landslides occurrence was previously predicted; high-risk areas mentioned include 1 and 10 and at low levels 3, 6, and 7. Construction density of Tabriz (b); residential parts less than $100 \mathrm{~m}$ are the most vulnerable to natural disasters (earthquakes, landslides, floods, etc.) 

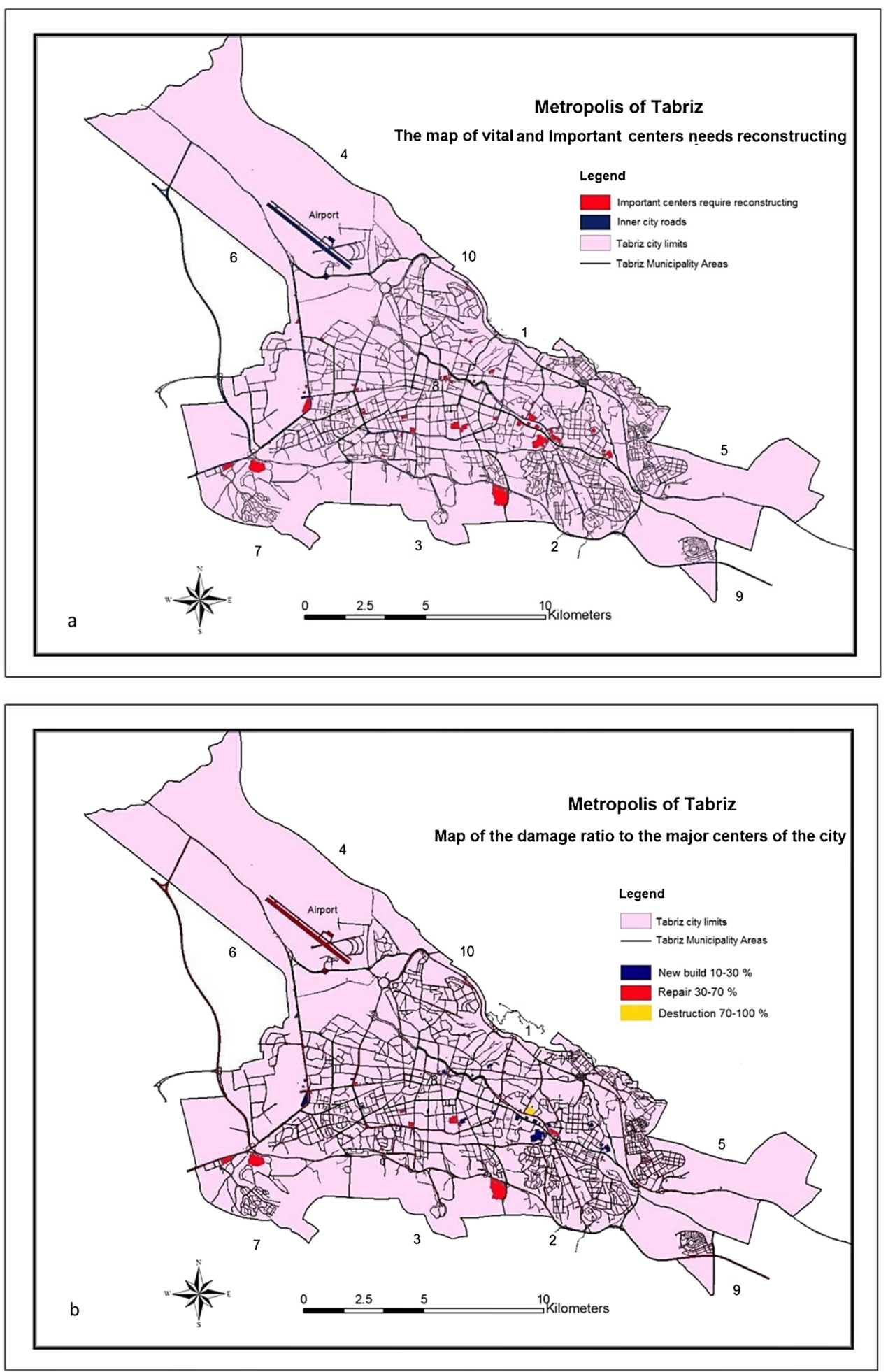

Fig. 10 Vital and important centers need reconstruction and reinforcement in Tabriz (a); to mitigate landslide impact, it is necessary to reinforce more than $70 \%$ of the important and vital centers in Tabriz. Damage ratios of the major centers of the city (b); red spots: some areas such as military, Bazar, and fire station that need to be rehabilitated. The blue dots represent some of the most important and vital new centers, including some training, administrative, military, and fire stations. The yellow dots represent a military site and training site which are in the range of destructive. According to civil engineering and urban planning, new buildings were 10 to $30 \%$ more vulnerable to accidents such as landslides. Buildings that required retrofitting had a vulnerability of about 30 to $70 \%$ and buildings that were very old and demolished had a vulnerability of about 70 to $100 \%$ to a landslide occurrence. Area requiring police and security centers (c), law enforcement, and security forces play a key role in controlling the psychological and social impacts of natural disasters such as landslides, preparing them to deal with their destructive effects 


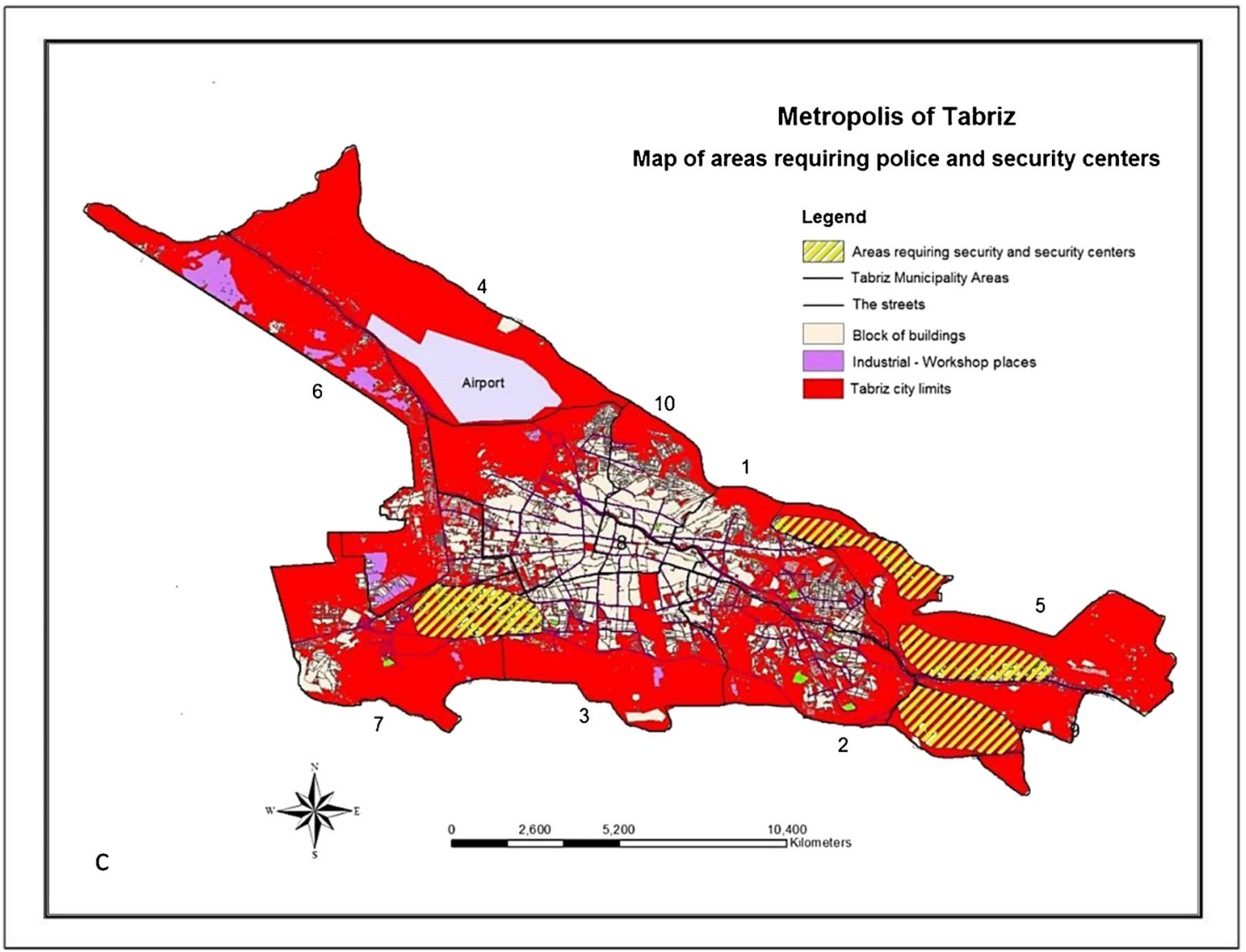

Fig. 10 continued.

Earth in 2020 with a scale of 1:4000 were entered into the GIS software. The average annual slip movement in a 27 -year period (1957 to 1984) was $53.29 \mathrm{~cm}$ per year, and in the 36year period (1984 to 2020), it was $75.72 \mathrm{~cm}$ per year. The increase in human activity in landslide-sensitive areas has led to the ascending increases in landslides between 1984 and 2020; over time, landslide areas have become more unstable. The results showed that the average speed of Tabriz landslides during 63 years is $41.65 \mathrm{~m}$ (Fig. 11; Table 12).

\section{Discussions}

This study showed that the EBF model is well able to detect landslides in urban areas; this deduction is consistent with the results of a credible study. The results of the landslide sensitivity assessment using the EBF model showed that $82.9 \%$ of the Tabriz area is at risk of landslide vulnerability. The output of the ROC curve showed $89.81 \%$ accuracy of the EBF model. This study showed that landslides occur at certain altitudes (Chen et al. 2019b). Areas above 1,700 m from sea level are more at risk of landslides due to human activities. In addition to similar and main criteria used in related articles (Hong et al. 2018), in this study, others such as distance from oil lines and gas networks were also used. The highest risk of explosion due to landslides in Tabriz in these high-risk lines is at a distance of $5,000 \mathrm{~m}$. Some researchers looking at the environmental impact of landslides also studied the impact of landslide vulnerability economic criteria (Postance et al. 2017). In this study, we also assessed environmental and social criteria. Regarding the economic impact, the road criterion, with an output weight of 0.477 , is the most vulnerable to landslides as a direct effect (road damage and blockage) and an indirect effect (traffic delay and reduced transport efficiency). Moreover, for the environmental impact, the output weight of the geological criterion was 0.396 , and for the social impact, the output weight of the recreation areas was 0.452 , which all showed the highest vulnerability to landslides in Tabriz. A survey of vital infrastructures in Tabriz revealed shortages in several areas, including medical and rescue facilities, security and enforcement centers, distribution of city facilities users, distribution of essential and vital centers, and green spaces; the quantity and quality of each play a critical role in reducing (or increasing) the severity of landslide vulnerability. The general trend of the results of this study revealed that the areas with a higher population density suffered from a poor economic situation; these areas were located downstream of the mountainous area and were more 

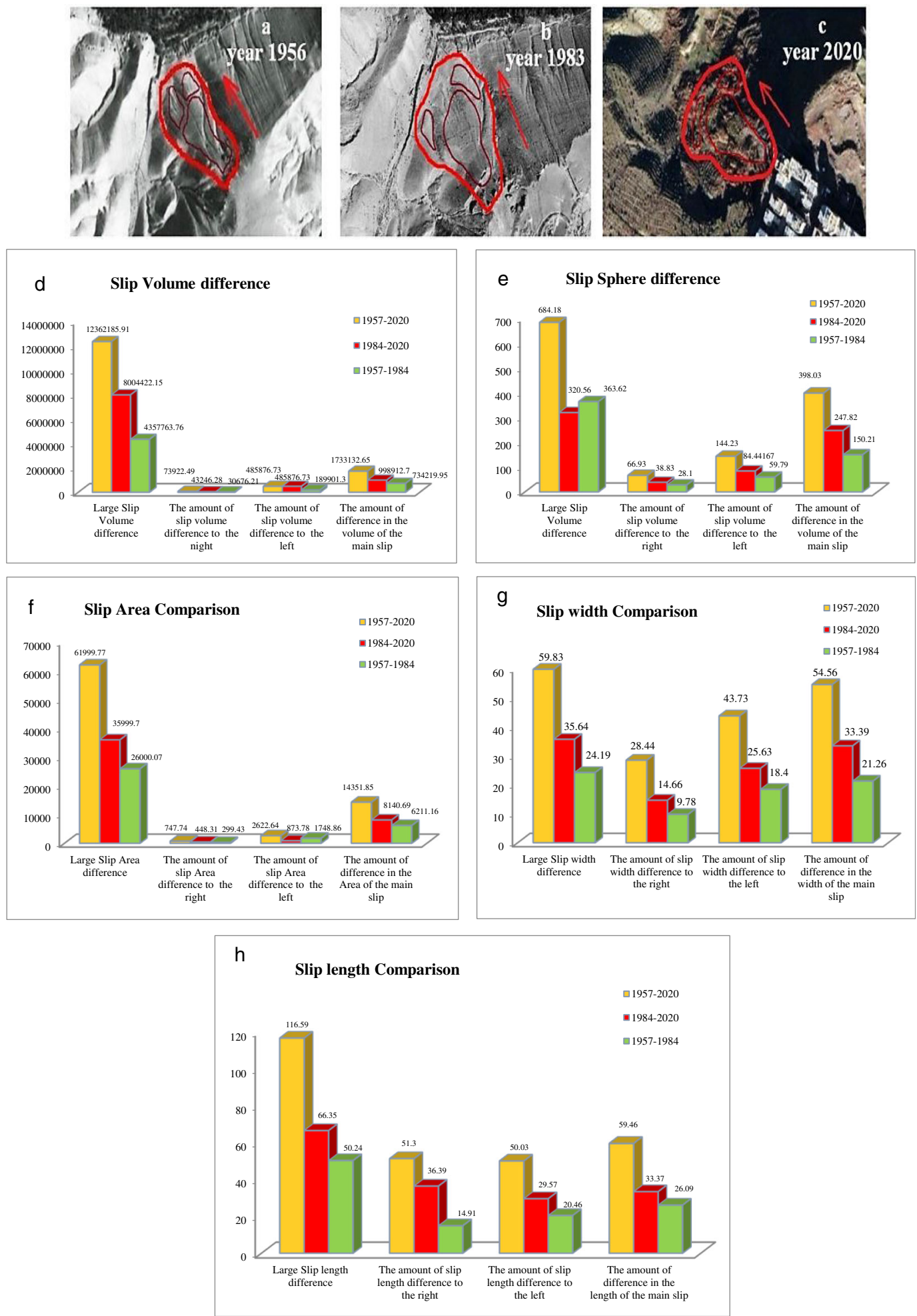

Fig. 11 Aerial photo and satellite image of the largest landslide in Tabriz. a Landslide aerial photo 1956. b Landslide aerial photo 1983. c Landslide satellite image 2020. The results showed that the average landslide movement in Tabriz over 63 years was about $41.65 \mathrm{~m}$. The graph of displacement rate and morphometric changes of landslide in Tabriz, slip volume difference (d), slip sphere difference (e), slip area comparison (f), slip width comparison (g), and slip length comparison (h). Analysis of the information obtained in the above diagrams shows that, due to the influence of lithological and human factors, the morphometric characteristics of the Tabriz landslide during the period 1956 to 2020 increased significantly 
Table 12 Total motion rate and annual average slip motion in the years studied

\begin{tabular}{llll}
\hline $2020-1956$ & $2020-1983$ & $1983-1956$ & Documents \\
\hline 66.11 & 75.72 & 53.29 & $\begin{array}{c}\text { Average annual slip } \\
\text { motion (cm/year) }\end{array}$ \\
41.65 & 27.26 & 14.39 & $\begin{array}{c}\text { Total amount of slip } \\
\text { motion (M) }\end{array}$ \\
\hline
\end{tabular}

vulnerable. The results showed that in terms of medical and rescue centers, there was 142 ha shortage, which directly affects approximately 6815 people in the northern and southeastern regions of Tabriz. In terms of equipment and facilities, 85-ha shortage affects 1814 people in the southwest, central, and northeast regions of Tabriz. Regarding per capita green and open areas, 430 ha shortage affected 3094 people in the southwest region and two regions in central Tabriz. Some vital centers in Tabriz need improvement, including educational centers, security, and market centers. In general, the severity of vulnerability to landslides can be minimized if the city's vital infrastructure is improved. The results of monitoring studies of the largest landslide in Tabriz in 1957 (first landslide occurrence first), 1984 (beginning of human activity in the landslide area), and 2020 showed approximately $41.65 \mathrm{~m}$ of landslide during 63 years. The statistical results of the Tabriz landslide monitoring program showed a gradual increase in the rate of landslide movement over time; the average annual sliding during 1983-2020 was higher than that from 1956 to 1983. This shows that Tabriz landslides have become more unstable and frequent over time, especially as human activities have recently increased in the area. The lack of geological documented data related to urban planning policy was the only statistical limitation in this research work. Different insights of this study provide a valuable and useful basis for more extensive regional and trans-regional research. The mentioned insights deal with the environmental behavior of landslides and the design of strategic policies to mitigate the effects of landslides. The importance of applying the results on an international scale can be summarized into three topics as follows. First, due to the high vulnerability of road criterion in terms of landslide potential, the importance of maintaining the infrastructure of the Tabriz-Turkey road network is revealed; it is the most important international transit road.

Table 13 Relationship between building size and degree of vulnerability

\begin{tabular}{ll}
\hline Vulnerability degrees & Building size \\
\hline High & area $<200$ \\
Average & $200<$ area $<500$ \\
Low & $500<$ area \\
\hline
\end{tabular}

The average size of residential plots is one of the factors affecting the slip vulnerability of urban structures
Second, due to the extent of the plateaus and interconnection of faults in neighboring countries, the occurrence of geological events in one of two neighboring border cities of neighboring countries leads to the stimulation of faults in the latter. Third, according to the 2009 cooperation agreement between Iran and the United Nations (UN) Office on Transatlantic Affairs, the study results are useful as internationally documented applicable spatial data concerning landslides, strategic policies in crisis management of geological events, and monitoring programs in the physical control of landslides.

\section{Conclusions}

Previous studies in Iran have focused on assessing the vulnerability to landslides. However, the influence of landslides in urban areas has not been analyzed by examining environmental, economic, and social vulnerabilities and needs to be investigated. This study is a prototype for assessing vulnerability in urban areas of a developing country. The objective of this study was to identify and predict locations of landslides in Tabriz, as it is one of the most important cities in Iran in terms of geography, economy, and politics. In this study, to improve the performance of government agencies and nongovernmental organizations (NGOs), it was necessary to assess the environmental behavior of landslides concerning the vulnerability of the population living in slippery areas. The results showed that the most landslide vulnerable areas were residential areas with a high population density and weak financial situations (Table 13). Moreover, these areas include low-density and compact structures with dramatically increasing vulnerability. Therefore, corrective measures must be taken in terms of the quantity and quality of services provided by the government and the health agencies. A natural disaster such as an earthquake or heavy rain will then lead to the destruction of high-risk buildings, significant casualties, and financial losses. Several general strategies can be proposed to manage the situation and reduce the effects of landslides in Tabriz. Short-term strategies include public education and lowcost mitigations such as gully and other drainage facilities. Monitoring and recording landslide data can also be useful to local authorities for the development and management of the city. Meanwhile, midterm strategies can include establishing an evidence-based decision-making guideline for defining essential projects and governance in areas highly affected by the landslide. Long-term strategies include changing the legal policy and administrative structure of urban development in areas at high landslide risk. In the long run, the high costs of these measures are offset, due to the prevention of post-slip maintenance and its associated costs. Control and maintenance measures may include daily observation, forecast, and assessment of slope slip fences and meteorological devices. Although these measures are described as low-cost operations, they have a significant impact on reducing slip risks. 
Acknowledgements We would like to thank the National Mapping Agency of Iran, the local government of Tabriz, and the professors of the Tehran University of Science and Research.

\section{Declarations}

Conflict of interest The authors declare that they have no competing interests.

\section{References}

Abbaszadeh Shahri A, Spross J, Johansson F, Larsson S (2019) Landslide susceptibility hazard map in southwest Sweden using artificial neural network. CATENA 183:104225. https://doi.org/10.1016/j. catena.2019.104225

Ahadnezhad Reveshty M, Kamelifar MJ, Ranjbarnia B, Pashaiifar A (2014) A comparative study on physical vulnerability of urban area against natural hazards: importance of health promoting approach in civil engineering. Health Promot Perspect 4(1):122-131. https://doi. org/10.5681/hpp.2014.016

Akawwi E, Al Assef A, Barghouthi A (2018) Landslide, rock fall hazard assessment and risk inventory maps at south Jordan. IJEEDC 6(3): $1-4$

Amarasinghe A, Perera E (2020) Modeling predictive suitability to determine potential areas for establishing wind power plants in Srilanka. Model Earth Syst Environ 7:443-454. https://doi.org/10.1007/ s40808-020-00868-w

Arasteh R, Abbaspour R, Salmanmahiny A (2019) Non-path dependant urban growth potential mapping using a data-driven evidential belief function. Environ Plan B Urban Anal City Sci 48(3):555-573. https://doi.org/10.1177/2399808319880219

Ayala A (2019) time in a bottle: challenges to disaster studies in Latin America and the Caribean. Disaster 43:18-27

Bičer C, Ercanoglu M (2020) A semi-quantitative landslide risk assessment of central Kahramanmarash city in the eastern Mediterranean region of Turkey. Arab J Geosci 13:732. https://doi.org/10.1007/ s12517-020-05697-w

Bui D, Pradhan B, Lofman O (2012) Spatial prediction of landslide hazards in housing province (Vietnam): a comparative assessment of the efficacy of evidential belief function and fuzzy logic models. CATENA 96:28-40. https://doi.org/10.1016/j.catena.2012.04.001

Bui DT, Tuan T, Pradhan B (2016) Spatial prediction model for shallow landslide hazards: a comparative assessment of the efficacy of support vector machines, artificial neural networks, kernel logistic regression and logistic model tree. Landslide 13(2):361-378

Chen W, Sun Z, Han J (2019a) Landslide susceptibility modeling using integrated ensemble weights of evidence with logistic regression and random forest models. Appl Sci 9(1):171. https://doi.org/10.3390/ app9010171

Chen W, Panahi M, Tsangaratos P, Shahabi H, Ilia I, Panahi S, Li S, Jaafari A, Ahmad BB (2019b) Applying population-based evolutionary algorithms and a neuro-fuzzy system for modeling landslide susceptibility. CATENA 172:212-231. https://doi.org/10.1016/j. catena.2018.08.025

Confuorto P, Di Martire D, Infante D et al (2019) Monitoring of remedial works performance on landslide-affected areas through ground- and satellite-based techniques. CATENA 178:77-89. https://doi.org/10. 1016/j.catena.2019.03.005

Contreras D, Chmorro A, Wilkinson S (2020) The spatial dimension in the assessment of urban socio-economic vulnerability related to geohazards. Nat Hazards Earth Syst Sci 20:1663-1687. https://doi. org/10.5194/nhess-20-1663-2020
Dempster AP (2008) The Dempster- Shafer calculus for statisticians. Int J Approx Reason 48(2):365-377. https://doi.org/10.1016/j.ijar.2007. 03.004

Deng X, Li L, Tan Y (2017) Validation of spatial prediction models for landslide susceptibility mapping by considering structural similarity. ISPRS Int J Geo-Inf 6(4):103. https://doi.org/10.3390/ijgi6040103

Dikshit A, Sarkar R, Pradhan B, Acharya S, Alamri AM (2020) Spatial landslide risk assessment at Phuentsholing, Bhutan. Geo Sci 10(4): 131. https://doi.org/10.3390/geosciences10040131

Fahad MGR, Nazari R, Bhavsar P, Jalayer M, Karimi M (2019) A decision-support framework for emergency evacuation planning during extreme storm events. Transp Res D Transp Environ 77: 589-605. https://doi.org/10.1016/j.trd.2019.09.024

Feby B, Achu AL, Jimnisha K, Ayisha VA, Reghunath R (2020) Landslide susceptibility modelling using integrated evidential belief function based logistic regression method: a study from Southern Western Ghats, India. Remote Sens Appl Soc Environ 20:100411. https://doi.org/10.1016/j.rsase.2020.100411

Feizizadeh B, Shadman Roodposhti M, Jankowski P, Blaschke T (2014) A GIS-based extended fuzzy multi-criteria evaluation for landslide susceptibility mapping. Comput Geosci 73:208-221. https://doi.org/ 10.1016/j.cageo.2014.08.001

Ferlisi S, Gullà G, Nicodemo G, Peduto D (2019) A multi-scale methodological approach for slow-moving landslide risk mitigation in urban areas, southern Italy. EMJEI 4(1):20. https://doi.org/10.1007/ s41207-019-0110-4

He H, Hu D, Sun Q, Zhu L, Liu Y (2019) A landslide susceptibility assessment method based on GIS technology and an AHPweighted information content method: a case study of Southern Anhui, China. ISPRS Int J Geo-Inf 8(6):266. https://doi.org/10. 3390/ijgi8060266

Hizbaron D, Baiquni M, Sartohadi J, Rijanta R (2012) Urban vulnerability in Bantul district, Indonesia-towards safer and sustainable development. Sustainability 4(9):2022-2037. https://doi.org/10.3390/ su4092022

Hong H, Liu J, Bui DT, Pradhon B, Acharya TD, Pham BT, Zhu AX, Chen W, Ahmad BB (2018) Landslide susceptibility mapping using J48 decision tree with Ada boost, bagging and rotation forest ensembles in the Guangchang area. CATENA 163:339-413. https:// doi.org/10.1016/j.catena.2018.01.005

Li L, Nahayo L, Habiyaremye G, Christophe M (2020) Applicability and performance of statistical index, certain factor and frequency ratio models in mapping landslides susceptibility in Rwanda. Geocarto Int 1-19. https://doi.org/10.1080/10106049.2020.1730451

Makan A, Fadili A (2020) Sustainability assessment of large-scale composing technology using PROMETHEE method. J Clean Prod 261: 121244. https://doi.org/10.1016/j.clepro.2020.121244

Mateos RM, López-Vinielles J, Poyiadji E, Tsagkas D, Sheehy M, Hadjicharalambous K, Liscák P, Podolski L, Laskowicz I, Iadanza C, Gauert C, Todorović S, Auflič MJ, Maftei R, Hermanns RL, Kociu A, Sandić C, Mauter R, Sarro R et al (2020) Integration of landslide hazard into urban planning across Europe. Landsc Urban Plan 196:103740

Murillo F, Steger S, Alcantara I (2019) Landslide susceptibility a statically-based assessment on a depositional pyroclastic ramp. J Mt Sci 16:561-580. https://doi.org/10.1007/s11629-018-5225-6

Nhu V-H, Shirzadi A, Shahabi H, Chen W, Clague JJ, Geertsema M, Jaafari A, Avand M, Miraki S, Talebpour Asl D, Pham BT, Ahmad BB, Lee S (2020) Shallow Landslide susceptibility mapping by random forest base classifier and its ensembles in a semi-arid region of Iran. Forests 11(4):421. https://doi.org/10.3390/ fl 1040421

Nsengiyumva JB, Luo G, Nahayo L, Huang X, Cai P (2018) Landslide susceptibility assessment using spatial multi-criteria evaluation model in Rwanda. Int J Environ Res Public Health 15(2):243. https://doi.org/10.3390/ijerph15020243 
Pandey VK, Tripathi AK, Sharma KK (2021) Implications of landslide inventory in susceptibility modeling along a Himalayan highway corridor, India. Phys Geogr 1-24. https://doi.org/10.1080/ 02723646.2021.1872857

Park S-J, Lee C-W, Lee S, Lee M-J (2018) Landslide susceptibility mapping and comparison using decision tree models: a case study of Jumunjin Area, Korea. Remote Sens 10(10):1545. https://doi.org/ $10.3390 /$ rs 10101545

Postance B, Hiller J, Dijkstra T, Dixon N (2017) Extending natural hazard impacts: an assessment of landslide disruptions on a national road transportation network. Environ Res Lett 12(1):014010. https://doi. org/10.1088/1748-9326/aa5555

Pradhan SP, Siddique T (2020) Stability assessment of landslide-prone road cut rock slopes in Himalayan terrain: A finite element method based approach. J Rock Mech Geotech Eng 12(1):59-73. https://doi. org/10.1016/j.jrmge.2018.12.018

Pradhan B, Abokharima M, Jebur M, Tehrany M (2014) Land subsidence susceptibility mapping at Kinta Valley (Malaysia) using the evidential belief function model in GIS. Nat Hazards 73(2):1019-1042. https://doi.org/10.1007/s11069-014-1128-1

Puente-Sotomayor F, Egas A, Teller J (2021) Land policies for landslide risk reduction in Andean cities. Habitat Int 107:102298. https://doi. org/10.1016/j.habitatint.2020.102298

Rezaei M, Torabi S, Tavakkoli-Moghaddam R (2019) Prioritizing disaster-prone areas for large-scale earthquakes' preparedness. Socio-Econ Plan Sci 67:9-25. https://doi.org/10.1016/j.seps.2018. 08.002

Sah N, Kumar M, Upadhyay R, Dutt S (2018) Hill slope instability of Nainital City, Kumaun Lesser Himalaya, Uttarakhand, India. J Rock Mech Geotech Eng 10(2):280-289. https://doi.org/10.1016/j.jrmge. 2017.09.011

Sassa K (2019) The Kyoto Landslide Commitment 2020: first signatories. Landslides 16(11):2053-2057. https://doi.org/10.1007/s10346-01901295-4

Schäfer AM, Wenzel F (2019) Global megathrust earthquake hazardmaximum magnitude assessment using multi-variate machine learning. Front Earth Sci 7(136). https://doi.org/10.3389/feart.2019. 00136

Shaaban F, Othman A, Habeebullah T, Metwaly M (2021) Geoenvironmental impact assessment of rock-cutting activities on the mountainous urban areas, western Saudi Arabia. Arab J Geosci 14(8):709. https://doi.org/10.1007/s12517-021-07081-8

Shafer G (1976) A mathematical theory of evidence. Princeton University Press

Shen S, Cheng C, Yang J, Yang S (2018) Visualized analysis of developing trends and hot topics in natural disaster research. PLoS One 13(1):e0191250-e0191250. https://doi.org/10.1371/journal.pone. 0191250

Shirani K, Pasandi M, Arabameri A (2018) Landslide susceptibility assessment by Dempster-Shafer and Index of Entropy models, Sarkhoun basin, Southwestern Iran. Nat Hazards 93(3):13791418. https://doi.org/10.1007/s11069-018-3356-2

Skilodimou HD, Bathrellos GD, Chousianitis K, Youssef AM, Pradhan B (2019) Multi-hazard assessment modeling via multi-criteria analysis and GIS: a case study. Environ. Earth Sci 78(2):47. https://doi.org/ 10.1007/s12665-018-8003-4

Tavakkoli Piralilou S, Shahabi H, Jarihani B, Ghorbanzadeh O, Blaschke T, Gholamnia K, Meena S, Aryal J (2019) Landslide detection using multi-scale image segmentation and different machine learning models in the higher Himalayas. Remote Sens 11(21):2557. https://doi.org/10.3390/rs11212575

Thi Ngo PT, Panahi M, Khosravi K, Ghorbanzadeh O, Kariminejad N, Cerda A, Lee S (2021) Evaluation of deep learning algorithms for national scale landslide susceptibility mapping of Iran. Geo Sci Front 12(2):505-519. https://doi.org/10.1016/j.gsf.2020.06.013

Tian C, Peng J, Zhang W, Zhang S, Wang J (2020) Tourism environmental impact assessment based on improved AHP and picture fuzzy PROMETHEE II methods. Technol Econ Dev Econ 26(2): 355-378. https://doi.org/10.3846/tede.2019.11413

Usman DN, Widayati S, Sriyanti S (2020) Geological based on area development: terrain genetic unit method. J Phys Conf Ser 1469: 012142. https://doi.org/10.1088/1742-6596/1469/1/012142

Vilímek V, Klimeš J, Ttito Mamani RV, Bastante Abuhadba J, Astete Victoria F, Champi Monterroso PZ (2020) Contribution of the collaborative effort of the Czech WCoE to landslide risk reduction at the Machupicchu, Peru. Landslides 17(11):2683-2688. https://doi. org/10.1007/s10346-020-01509-0

Whiteley JS, Chambers JE, Uhlemann S, Wilkinson PB, Kendall JM (2019) Geophysical monitoring of moisture-induced landslides: a review. Rev Geophys 57(1):106-145. https://doi.org/10.1029/ 2018RG000603

Youssef AA, Al-Kathery M, Pradhan B (2015) Landslide susceptibility mapping at Al-Hasher Area, Jizan (Saudi Arabia) using GIS-based frequency ratio and index of entropy models. Geo Sci J 19(1):113134. https://doi.org/10.1007/s12303-014-0032-8

Zhao X, Chen W (2020) Optimization of computational intelligence models for landslide susceptibility evaluation. Remote Sens 12(14):2180. https://doi.org/10.3390/rs12142180

Zhou C, Yin K, Cao Y, Ahmed B, Li Y, Catani F, Pourghasemi HR (2018) Landslide susceptibility modeling applying machine learning methods: a case study from Longju in the Three Gorges Reservoir area, China. Comput GeoSci 112:23-37. https://doi.org/10.1016/j. cageo.2017.11.019 